\title{
Challenges, Opportunities and Recent Advances in Sugarcane Breeding
}

\author{
Katia C. Scortecci ${ }^{1}$, Silvana Creste ${ }^{2}$, Tercilio Calsa Jr. ${ }^{3}$, Mauro A. Xavier2 ${ }^{2}$, \\ Marcos G. A. Landell2, Antonio Figueira ${ }^{4}$ and Vagner A. Benedito ${ }^{5^{*}}$ \\ ${ }^{1}$ Department of Cell Biology and Genetics, Universidade \\ Federal do Rio Grande do Norte (UFRN), Natal, RN \\ ${ }^{2}$ Centro de Cana - Instituto Agronômico de Campinas (IAC), Ribeirão Preto, SP \\ ${ }^{3}$ Department of Genetics, Universidade Federal de Pernambuco (UFPE), Recife, PE \\ ${ }_{4}^{4}$ Plant Breeding Laboratory, Centro de Energia Nuclear na Agricultura (CENA), \\ Universidade de São Paulo (USP), Piracicaba, SP \\ ${ }^{5}$ Laboratory of Plant Functional Genetics, Genetics and Developmental Biology Program, \\ Plant \& Soil Sciences Division, West Virginia University (WVU), Morgantown, WV \\ 1,2,3,4 Brazil \\ ${ }^{5}$ USA
}

\section{Introduction}

Sugarcane (Saccharum spp.) has a long history in line with European colonization and Imperialism. Its cultivation in the New World since the early Modern Period (XVI century) largely shaped social structures, national and international politics, global trading, slavery, culinary, and even disease proliferation (tooth decay, diabetes, obesity) with extensive significance to current history around the globe (cf. Hobhouse, 2005; Rogers, 2010). In 2009, 1,682 million metric tonnes (MT) of sugarcane were produced worldwide in a total area of 23.8 million hectares (ha) (close to the size of the United Kingdom, which occupies 24 million ha). Brazil is the largest sugarcane producer, contributing with $40 \%$ of the world production (700 MT in 2009), followed by India (285 MT), China (114 MT), Thailand (67 MT), Pakistan (50 MT), Colombia (38.5 MT), Australia (31 MT), Argentina (30 MT), United States (27.5 MT), Indonesia (26.5 MT) and the Philippines (23 MT) (http://faostat.fao.org). Sugarcane is also an economically important crop for the economies of Mexico and many countries in Central America, the Caribbean, Africa, and Southern Asia (Fig. 1).

Sugarcane is native to southeastern Asia, with its cultivation in India dating since before 5,000 years ago (Daniels \& Daniels, 1975; Daniels \& Roach, 1987). This species has C4 photosynthesis, resulting in a vigorous biomass accumulation under tropical conditions, but it also implies a less vigorous growth in temperate regions. In commercial settings, sugarcane is clonally propagated via stem cuttings, facilitating the preservation of cultivar genetic identity. The plant is semi-perennial, with a cycle ranging from $\sim 12-18$ months from planting to harvest at tropical conditions, and regrowth of ratoons (sugarcane stumps) that allow up to five harvests. 
Sugarcane plantations are often criticized for occupying large extensions of fertile arable land that otherwise could be used for food production (the so-called "food or fuel" debate), for impacting the environment with deforestation and land degradation, monoculture, pollution (contamination of ground water via leaching and water bodies via run off of fertilizers, pesticides and molasses; pre-harvest burning and air pollution). It also relies heavily on low-paid seasonal jobs, and having many cases of labor abuses worldwide (child labor, slavery regimen, hazardous conditions, underpayment) (Martinelli \& Filoso, 2008; Miranda, 2010; Uriarte et al., 2009). Nevertheless, it produces an alternative and renewable energy source with balanced carbon emission (Goldemberg et al., 2008).

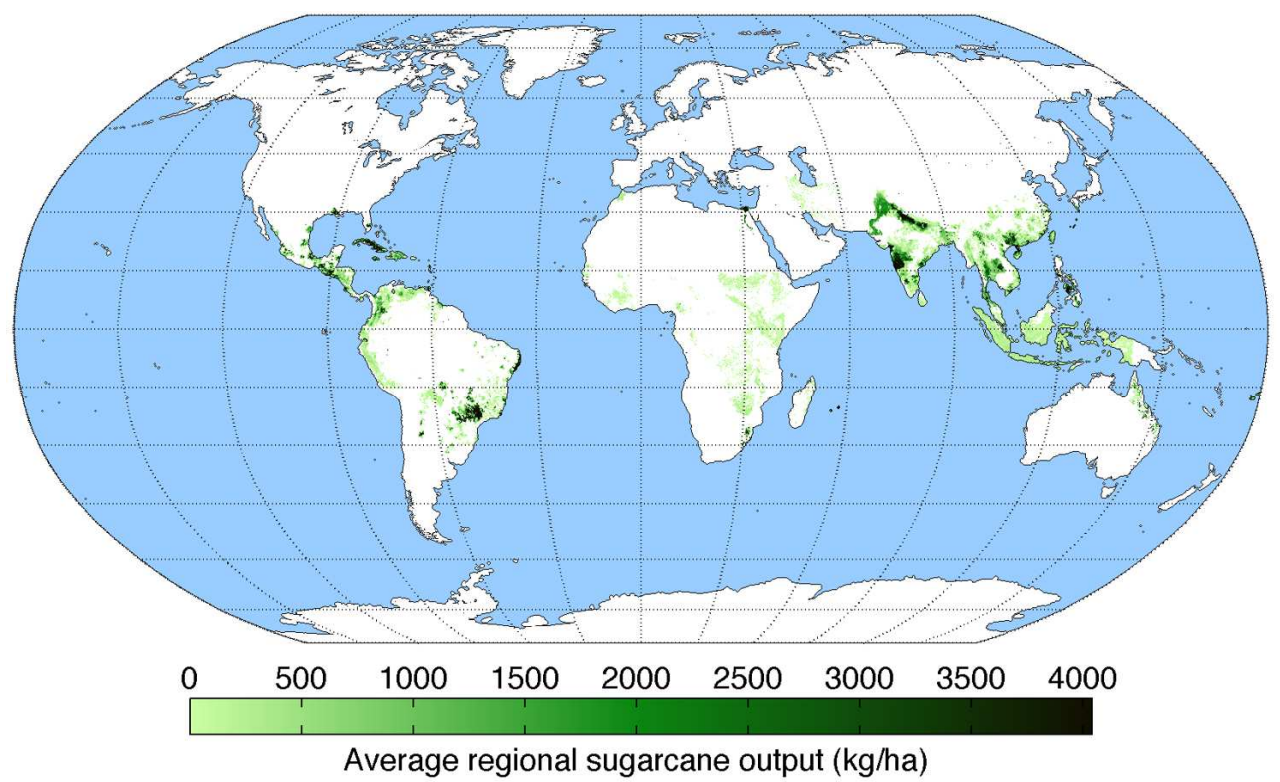

Fig. 1. Sugarcane production areas around the globe. Source: AndrewMT, http://en.wikipedia.org/wiki/Sugarcane

The sustainability of ethanol production as a component of the energetic base of a country is highly dependent on how the source crop is managed, and this also depends on the genetic background of cultivars available to farmers. Modern agricultural practices depend heavily on high input of inorganic fertilizers. The answer for the huge challenges regarding energy production the world currently faces may lie on sugarcane. However, one has to consider the convoluted origin and genetics of sugarcane, the complex system required for a sustainable, productive and profitable cropping, the social and ecological aspects. The massive demand for a reliable source of energy can only be answered with sugarcane if sustainability and the social issues is resolved. Most of the technical issues related to sugarcane feedstock production for biofuel to meet the massive bioenergy demand can be solved genetically, via breeding programs that will have to look more seriously to production systems with lower input of resources (energy, water, fertilizers, pesticides). Efforts should not overlook traditional and modern breeding techniques, including biotechnological tools to achieve its goals in a timely manner. 
Like no other contemporary crop, sugarcane is facing new paradigms and expected to at least partially solve one most important problems in present society: energy production. In this chapter we introduce the current status, potential and the new breeding challenges imposed to sugarcane crop, with a focus in Brazil as a model for sugarcane production. We further describe important traits for sugarcane production, delineate the breeding pipeline, and introduce recent advances in sugarcane genetics and genomics.

\section{Current and potential utilization of sugarcane}

Sugarcane is responsible for $\sim 70 \%$ raw table sugar production worldwide (Contreras et al., 2009), with the remaining production coming from sugar beet in temperate countries. Sugarcane stores energy as the non-reducing disaccharide sucrose, which accumulates in large amounts in the vacuoles of parenchyma cells of stem tissues (up to $23 \% \mathrm{w} / \mathrm{v}$, or 70 $\mathrm{mM}$; Hawker, 1965). This organic compound is especially used for producing table sugar (via simple crystallization of sucrose from stem juice and further refining and clarification), ethanol and spirits such as rum and "cachaça" (via yeast fermentation of the stem juice and distillation). Moreover, chopped sugarcane stalks are widely used as cattle feed, especially during dry season when pastures are unavailable for grazing.

Sugarcane is considered a first-generation biofuel crop. In Brazil, most energy converted to ethanol biofuel is derived from the sucrose extracted from squeezing the stems and fermenting the juice. However, only a third of the plant's energy is extracted using this technology, with the remaining being stored in less readily available compounds, such as the cellulose deposited in plant cell walls. Today in refineries located in São Paulo state, Brazil, bagasse is burned to provide heat for distillation of the fermented must during ethanol purification and to co-generate electric power that is sold to the electric power grid. More efficient ways to use the cellulosic energy are being sought in order to increase ethanol yields at the refinery.

Plant cell walls are mainly composed by cellulose, hemicellulose and lignin. Cellulose is a polysaccharide consisting of linked $\left[\begin{array}{ll}\beta & 1 \rightarrow 6\end{array}\right]$ glucose units, making around a third of the plant dry matter. The second generation of biofuels relies on the development of an efficient process of breaking down cellulose (thermally or enzymatically) into fermentable sugars from the bagasse and leaves. Current research goals in this regard are looking for: 1) plant varieties with improved constitution of cell wall contents to yield more cellulose and less lignin (Pandey et al., 2000; Ragauskas et al., 2006), 2) better methods for mechanic harvesting with low environmental impact, 3) use of the whole aerial plant parts as substrate for ethanol production, 4) use of high-pressure boilers to allow access to cellulose by the fermenting microorganisms and 5) genetically improved yeast strains with higher enzymatic capacity, including fermentation of pentoses. Special attention has also been given to novel product development from sugarcane industrial residues, or even from sucrose or ethanol, as a base for chemical synthesis of other organic molecules with higher market value such as xylitol and polyethylene glycol. In this context too, cellulose, hemicelluloses and lignin are acquiring increased relevance.

It is common practice (although not legal in many regions) to burn sugarcane fields to facilitate manual harvest. When fields are located near urban areas, this burning leads to air pollution and affect the population with smoke and carbonized particulates, which may 
lead to respiratory diseases and general population dissatisfaction. However, non-burned fields are quite hazardous to harvesters, as they have to cope with stinging stem trichomes, sharp leaf edges, and potential poisonous organisms, such as snakes, insects and spiders. By using mechanical harvesting, not only burning can be eliminated, but also along with the bagasse, the straw can be used in the refinery to either generate heat and electricity, or potentially be hydrolyzed to generate ethanol using second-generation technology, which should be more power efficient. Given the scale of ethanol production in Brazil, the energy stored in the straw and bagasse of sugarcane would be enough to generate up to ten gigawatt $(\mathrm{GW})$ power, which is close to the $14 \mathrm{GW}$ generated by the largest hydroelectric power plant in Brazil (Itaipu). This power plant supplies one fifth of the electricity consumed in Brazil and over 90\% of the energy used in Paraguay (Lora \& Andrade, 2009; Ripoli et al., 2000). The potential of biomass (bagasse and straw) energy generation in Brazil has been recently calculated to be over 25 GW (Azevedo \& Galiana, 2009).

A major by-product of ethanol distillation is vinasse, a complex liquid residue derived from distillation of the fermentate that is rich in humic acids (soluble organic matter) and minerals (such as K and P). For every liter of ethanol distilled, 10-20 liters of vinasse is left over, which have been used as fertilizer in sugarcane fields, saving millions of liters of water and improving the physical conditions of the soil. Vinasse application to sugarcane fields allows the recycling of nutrients back to the soil. However, its application in the field requires careful procedures to avoid contamination of water tables (Amorim et al., 2011). Another potential destination of vinasse is biogas production (Gonçalves et al., 2009).

With a largely diversified energy basis, Brazil (with a population of 192 million, according to the 2010 census) is a worldwide model on how a large country can efficiently establish a renewable and diversified energy matrix. According to the Brazilian Ministry of Mines and Energy, the energy produced in 2008 in the country was $46 \%$ renewable, with $15 \%$ derived from hydroelectric, 16\% from sugarcane, $12 \%$ from coal and wood, and 3\% from others sources. In sugarcane refineries, $20 \%$ of the energy used in boilers comes from bagasse, the remaining fibrous matter after juice extraction from sugarcane stalks, whereas wood encompasses 7\% (Cortez, 2010).

Land usage is an important economical and social issue to be considered during biofuel discussions. To meet the internal and global demand, Brazil needs to at least double its current ethanol production (Goldemberg, 2010; Waclawovsky et al., 2010). Sugarcane fields occupy 2\% of agriculture land in Brazil (Goldemberg, 2010), and ethanol derived from sugarcane is currently responsible for $\sim 50 \%$ of vehicle fuel in Brazil, where a biofuel program is in place since 1975 with the successful aim of relieving the nation's external dependence on oil (Leite, 2010). Yield has increased on average $\sim 1.2 \%$ per year (considering a compound rate) in the last three decades in Brazil, while production increased almost fivefold (http://www.faostat.org), and sugarcane-based ethanol yield increased $3.8 \%$ per year between 1975 and 2004 (Goldemberg, 2008).

More recently, concerns on global warming and its association with human activities via $\mathrm{CO}_{2}$ emissions and greenhouse effects, together with the foreseeable depletion of fossil fuel supply, launched a worldwide search for alternative energy sources that should be renewable and sustainable. During the mid-1990s, engines that accept both ethanol and gasoline (or a mixture) fueled the industry of flex fuel vehicles (i.e., with engine enabled to 
use any ratio of ethanol and gasoline blend) and is gaining market momentum in many countries with a worldwide increasing demand for ethanol production (Leite et al., 2009). The Brazilian Alcohol Program (Proalcool) helped to establish a massive bioethanol industry in the country along with the pioneer development of the ethanol-based internal combustion car engine (Grad, 2006), relieving the country of a heavy dependence on foreign petroleum and external market fluctuations. Brazil is the pioneer in flex fuel technology, and currently $\sim 95 \%$ of the vehicles sold in Brazil are flex fuel. Blending ethanol into gasoline is also a current worldwide trend to relieve gas emissions derived from fossil fuels as well as to lower fuel costs. For comparison, net production costs of ethanol derived from several crops was estimated in 2004 (Henniges \& Zeddies, 2004), with Brazilian sugarcane-derived ethanol for $15 € / 1,000 \mathrm{~L}$, while the same amount of ethanol was produced from U.S. corn for $24 €$, from German wheat for $48 €$ and from German sugar beet for $52 €$ per $1,000 \mathrm{~L}$. The net energy balance (i.e., energy derived from processing in relation to input energy to produce the fuel) of sugarcane ethanol is between 8.2 and 10-fold while it is $\sim 1.3$ for fossil fuels (Goldemberg, 2008; Hill et al., 2006), although these figures are controversial. The cost of sugarcane-derived ethanol in Brazil was calculated as US\$30-35 per barrel of oil-equivalent (i.e., the amount of energy contained in a barrel of oil), whereas the corn-derived ethanol from U.S. was estimated as US $\$ 45-50$ in the same period (Nass et al., 2007).

Other crops have more recently been target as biofuel crops, such as sugar beet (Beta vulgares), corn (Zea mays), switchgrass (Panicum virgatum), sweet sorghum (Sorghum bicolor), Brachipodium (Brachypodium distachyon), and Miscanthus (Miscanthus giganteus) (Goldemberg, 2008; Vega-Sánchez \& Ronald, 2010). Oil-producing species (soybean, corn, sunflower, oil palm, algae, etc) are also considered alternative sources of sustainable biodiesel via transesterification reactions (i.e., the process of exchanging the organic group $\mathrm{R}^{\prime \prime}$ of an ester with the organic group $\mathrm{R}^{\prime}$ of an alcohol). This carries higher power density than ethanol, and should be accounted in a diversified equation of energy matrix of a nation. However, sugarcane is considered the best biofuel crop in equatorial and tropical regions because of its yield and production costs (Goldemberg, 2008).

Together with expanding land occupation with sugarcane fields, improvement in crop and ethanol yields must be achieved. Crop yield in São Paulo, Brazil is expected to increase 12\% over the next 10 years, with an $6.4 \%$ increase in total recoverable sugar, $6.2 \%$ in fermentation efficiency with improved yeast strains, and $2 \%$ in sugar extraction in the same period, adding to an overall increase of $29 \%$, reaching $7,000-9,000 \mathrm{~L}$ ethanol per hectare (Goldemberg, 2008), with a perspective of reaching >14,000 L/ha in the next 20 years.

\section{Limitations to production and breeding goals}

\subsection{Breeding programs}

Sugarcane breeding programs play an essential role for the sugar-alcohol industry, as they are responsible for the development of cultivars, which consists of the major technological input for sugar and alcohol production. Sugarcane research and breeding programs have been very successful in Brazil, encompassing an agribusiness model of private and public funding integration. Fostered by government programs and focused research programs, São Paulo state is the major sugarcane producer in the country. Its production participation in Brazil rose from $20 \%$ in 1929, to $50 \%$ in 1970 , and to $87 \%$ at present (Cortez, 2010). Breeding 
programs are partially responsible for this success, as they were able to deliver genotypes with superior traits, responding to new challenges that occasionally arise.

The basis of the germplasm for sugarcane breeding involves commercial varieties and Saccharum-related species. Because the major subtropical production regions in Brazil do not favor flowering, parental plants are cultivated in farms with more tropical conditions (such as in Bahia, Brazil) and used for crossing to obtain seeds. Segregating seeds are then distributed to diverse locations for field selection, which may occur twice a year. Plant selection is carried out in three phases, and new genotypes can be exchanged between institutions, especially the governmental ones. The best clones are identified, multiplied and tested in farms during the experimental phase. The release of a new variety may take 12-13 years, after being tested for genetic stability, performance, and agronomic traits (Gazaffi et al., 2010; Landell, 2003; Landell et al., 2010). The success of breeding program depends largely on the choice of parental genotypes, trait heritability, evaluation period, statistic model used, and clone evaluation (Gazaffi et al., 2010). Moreover, the breeder has to pay attention to environmental conditions. In variety development, all factors that may affect production, such as biotic and abiotic stresses (including future threats) have to be considered by breeders.

\subsection{Production challenges}

Until recently sugarcane had been bred mostly for high sucrose content, because sucrose was the main substrate to produce sugar and ethanol. Thus, there has not been a current distinction of sugarcane genotypes since both first-generation technology of ethanol and raw sugar production rely on extractable sucrose accumulation in the stalk. This is advantageous for the sugarcane industry, as processing factories are capable of producing both sugar and/or ethanol, the choice of which product to make is dictated by the demand for each commodity. With the advent of the second-generation ethanol that now relies on cellulose, sugarcane breeding programs will have to revisit their genetic pools. Traits of high cellulose content in sugarcane tissues will be introduced to deliver specialized genotypes that use metabolic energy towards accumulation of either sucrose or cellulose, thus diverging breeding programs to specific goals.

The challenge to increase biofuel production in the coming years (Lam et al., 2009; Melo \& Poppe, 2010) can be achieved by expanding the cultivation area, increasing yield with new varieties and improving the whole production system from sugarcane management, harvesting, ethanol production and innovation on sugar and ethanol mills. Beyond the overall increase in carbohydrate yield (sucrose or total biomass), other traits are important to consider addressing the major challenges in production systems, such as better fitness against stresses classified as biotic (pests, diseases, weed competition) and abiotic (drought, salinity, cold, aluminum toxicity, poor and compacted soils), flowering, plant vigor (fast growth under limiting conditions), and plant architecture including height, stalk number, tillering, leaf angle (Carvalho, 2010; Creste et al., 2010).

\subsection{Specific goals of breeding programs}

\subsubsection{Production goals}

A key goal of sugarcane breeding programs is to increase sugar yield by increasing sugar production per area, which is closely associated with height, diameter and number of the 
stalk, along with sugar accumulation in the stalk. Sugar yields have been generally improved by increasing total biomass rather than directly increasing sugar concentration in stalks (Jackson, 2005). Regarding sugar accumulation in the cane, stalk diameter seems more important than length (Milligan et al., 1990). Other important traits to be considered are vigor and productivity of the ratoon (Aitken et al., 2008). Future varieties bred specifically for second-generation biofuels will be dissociated from high-sucrose yields, but instead will aim at total biomass production per area.

Brix weight per stool (BW) in sugarcane is a genetic trait derived from the combination of many components. This trait was deconvoluted to five genetic components using a sophisticate statistics tool. Some traits are additive while others present dominant effects. Additive effects can be useful for breeding in early generations of the program while dominant effects are more useful in hybrids (Liu et al., 2007). Increase of sugar yield (tons of pol per hectare, TPH) has always been a major goal of breeding programs. TPH Sugarcane clones are selected on the basis of $\mathrm{TPH}$, estimated by the product of mass yield (tons of sugarcane per hectare, TSH), and \% Pol (sucrose content) of the stem juice. Thus, TPH increment is of great economic interest, considering that costs of harvesting, transportation and grinding remain constant. Casu et al. (2005) proposed that sugar accumulation in stalks might be regulated by a network of genes that contribute to physiological process and abiotic stress tolerance. Papini-Terzi et al. (2009) observed an overlap between pathways related to sugar accumulation and drought stress. Iskandar et al. (2011) analyzed 51 genes related to abiotic stress and affecting sugar accumulation, and concluded that changes in gene expression as a response to water deficit involves different mechanisms, including genes related to biochemistry as well as development.

Another aspect to be considered in biomass production is maximization of radiation interception. It is proposed to potentially increase $10-15 \%$ production when the cultivar and plant density is combined with the appropriate planting date (either in planted or ratoon crops) (Singels et al., 2005), being key for crop management. Furthermore, as research on second-generation ethanol production is taking off, breeding programs are looking for traits that increase the lignocellulosic biomass. Another important aspect of plant anatomy to consider is the development of straight stalks in order to best adequate mechanical harvesting (Castro, 2010; Vega-Sánchez \& Ronald, 2010).

\subsubsection{Tolerance to abiotic stresses}

Stress can be defined as any condition that hampers the expression of the full genetic potential of a living being. As sessile organisms, plants face many stressful conditions that required the evolutionary establishment of diverse developmental and physiological strategies to cope or avoid the stress condition. However, these strategies usually require metabolic energy that should rather be directed to useful production.

Water deprivation or scarcity is a major abiotic stress for sugarcane. Elucidating tolerance mechanisms would enable the development of cultivars more tolerant to drought, allowing cultivation in marginal areas, while assuring the sustainability and viability of the industry in such drought-prone areas. Plant irrigation is a good option for agriculture but it also increases salinity on soil. Besides, it corresponds to $65 \%$ of global water demand and considering the expansion of cultivation to areas without fresh water, tolerance to drought 
will become increasingly important. Drought tolerance would also contribute to reduce irrigation and water use (Rocha et al., 2007). Even though sugarcane can survive long dry periods, it demands a fair amount of water for optimal yield, leading to the use of irrigation in many areas. Whereas irrigation of sugarcane plantations in Brazil is minimal, $60 \%$ of Australia fields and $40 \%$ of South African cultivation are irrigated (Innam-Bamber \& Smith, 2005). However, the lack of genetic and molecular information about drought tolerance mechanisms and inheritance in sugarcane has limited the development of improved cultivars. There is a need to distinguish genes definitely associated with the response to water deficit, which hold an adaptive function to water deprivation and in stress environments. Genes associated with regulation of expression under water deficit or during the establishment of drought tolerance are potential candidates to evaluate differential expression between contrasting sugarcane genotypes. Studies conducted with rice, Arabidopsis and sugarcane have used microarray analyses (Seki et al., 2001, 2002; Yamaguchi-Shinozaki et al., 2002; Rabbani et al., 2003; Rocha et al., 2007), with subsequent validation through quantitative amplification of reversed transcripts (RT-qPCR). This is to further investigate differentially expressed genes at distinct moments during drought. Some studies have used these differentially expressed genes to obtain transformed plants more tolerant to water deficit (Kirch et al., 2005; Zheng et al., 2004). The identification of genes encoding structural proteins directly related with the establishment of drought tolerance could be useful to develop genetic markers to select tolerant and/or sensitive genotypes. This helps to obtain improved cultivars by direct manipulation (transgenic) or classical breeding. Microarrays data have showed a change in gene expression by drought conditions. In sugarcane 93 genes were differentially expressed, including orthologs of NAC and DREB transcription factors and the cysteine proteinase RD19A (Koizumi et al., 1993; Papini-Terzi et al., 2005; Tran et al., 2004; Yamaguchi \& Shinozaki, 2006). Indeed, this knowledge led to the development of transgenic sugarcane more tolerant to drought (see section on Biotechnology).

\subsubsection{Resistance to biotic stresses}

Genetic resistance to pests and diseases is a sine qua non (i.e., indispensable and essential condition) in plant breeding. Pests and pathogens often conquer new territories and are well known to dynamically evolve towards breaking resistances, always posing new challenges. Indeed, biotic stresses are of special concern in sugarcane breeding programs, because they may cause great economical impact in plantations with susceptible cultivars.

Examples of biotic stresses to which sugarcane breeders, geneticists, pathologists, entomologists have been paying attention, depending on the location of the breeding program are fungal diseases such as rusts [especially the "brown rust" (Puccinia melanocephala) and the "orange rust" (Puccinia kuehnii), which recently invaded the American continent], as well as "smut" (Ustilago scitaminea). The main bacterial diseases are "ratoon stunting disease" (Leifsonia xyli) and "leaf scald" (Xanthomonas albilineans), and important viral diseases are "sugarcane mosaic virus" (SCMV) and "sugarcane yellow leaf virus" (SCYLV). Additional diseases with constrained proliferation or of potentially less significant economical impact comprise the fungal diseases "red rot" (Glomerella tucumanensis), "eye spot" (Helminthosporium sacchari), "pokka boeng" (Fusarium moniloforme), and "pineapple disease" (Ceratocystis paradoxa). Identification of genetic resistance for these diseases is 
important to allow incorporation of resistance traits as goals in breeding programs to reduce production threats (current and potential), as well as reduce fungicide spraying.

In the same context, insects are also potential threats to sugarcane production, either directly or as disease vectors. The main sugarcane pests include root froghopper (Mahanarva fimbriolata, Hemiptera: Cercopidae), the sugarcane weevil (Sphenophorus levis, Coleoptera: Curculionidade), longhorn beetle (Migdolus fryanus, Coleoptera: Cerambycidae), sugarcane borer (Diatreae saccharallis, Lepdoptera: Pyralidae), and the stem borer (Telchin licus, Lepdoptera: Castniidae). Whereas aphids are of little concern as pests per se, two species (Melanaphis sacchari and Sipha flava, Hemiptera: Aphididae) are SCYLV vectors. Sugarcane resistance against these insects is beneficial where the virus is a potential danger. Biological control of sugarcane pests by using natural enemies is a viable crop management technique in some cases, such as the fungus Metarhizium anisopliae that controls the root froghopper. However, the incorporation of genetic resistances against pests of economical or potential impact is indisputably the best option, when available.

\subsubsection{Desirable developmental traits}

Flowering induction: In sugarcane flowering is regulated by photoperiod (short day), temperature, humidity, plant age, and soil fertility. Flowering induction occurs when photoperiod decreases to more than 11.5-12.5 hours, depending on cultivar (Araldi et al., 2010; Moore \& Nus, 1987). Panicle development and pollen fertility temperature is favored by $\sim 28^{\circ} \mathrm{C}$ day $/ 23^{\circ} \mathrm{C}$ night cycles (Clements \& Awada, 1967). When sugarcane flowers, the plant stops growing, and sugars accumulated in the stalks are used for reproductive development, followed by plant senescence, as the plant's life cycle closes (Araldi et al., 2010). On the other hand, flowering is an important trait for breeding. Economic production of sugarcane in Equatorial areas is hampered by climatic conditions, as flowering may occur all year around, because photoperiod is always close to $12 \mathrm{~h}$ (Clements \& Awasa, 1967). The location of sugarcane breeding stations is favored in these areas. S. officinarum shows a generally low flowering index in favorable conditions, which is used as an important source of this trait in breeding programs (Cheavegatti-Gianotto et al., 2011).

Plant architecture: it is composed mainly of three traits: tillering, stalk diameter and stalk height (Carvalho, 2010; Creste et al., 2010), as important aspects in determining biomass production. Leaf angle is also an important trait to consider, because shadowing of lower leaves by the upper ones leads to lower photosynthetic rates. More recently, a straight stalk development is sought in new cultivars to facilitate mechanic harvest. The genetics of these developmental traits are not well established in sugarcane and breeding programs. It must rely on performance field selection, making sugarcane germplasm evaluation a long-term effort.

Ratooning capacity: Ratoons can regrow after each harvest, although with decreased vigor, which allows on average five productive harvests before the necessary renovation of the field. This is a very important trait to take into consideration during the evaluation period of breeding programs, because poor ratooning capacity will compromise the longevity of the established plantation.

\subsubsection{Important physiological traits to be considered}

Nitrogen use efficiency: Nitrogen is one of the most expensive plant fertilizers, because the conversion of atmospheric nitrogen $\left(\mathrm{N}_{2}\right)$ to ammonia $\left(\mathrm{NH}_{3}\right)$ is produced commercially using 
the Haber-Bosch process, which is energetically demanding (Erisman et al., 2008). Sustainable production systems necessarily involve low demands of inorganic nitrogen. Interestingly, sugarcane is able to establish a mutualistic symbiosis with diazotrophic endophytes that reside in xylem cells (especially the bacteria Glucoacetobacter diazotrophicus; Cavalcante \& Dobereiner, 1988) and in the rhizosphere (such as bacteria of the genera Azotobacter, Azospirillum, Beijerinckia, Derxia, Enterobacter, and Erwinia) (Thaweenut et al., 2011), which partially supply the plant's requirement of nitrogen, and contributes to minimize nitrogen fertilizer applications, at least under Brazilian conditions (Giller, 2001). Recently, G. diazotrophicus had its complete genome sequenced (Bertalan et al., 2009), which will help to understand the symbiotic interaction between this prokaryote and sugarcane at the genetic and molecular levels with perspectives of increasing symbiotic nitrogen supply to sugarcane plants. There are also indications that modern varieties can improve efficiency use of inorganic nitrogen via genetic breeding with focus on plant's physiology (Whan et al., 2010), which could be highly beneficial in breeding programs.

Mycorrhizal association: Another important symbiotic association involves mycorrhizae and roots, which improves the plant's nutrient uptake (notably phosphate, but also nitrogen and possibly water and other nutrients). Reis et al. (1999) analyzed the sugarcane rhizhosphere composition in three Brazilian regions and observed the presence of 14 distinct arbuscular mycorrhizae (AM) species, being Glomus the most representative, with the fungal diversity maintained when the field is not burned. Since this association is energetically demanding for the plant, which supplies the fungus with carbon skeletons in exchange for nutrients, the plant tightly controls this symbiosis. Low P soil conditions (e.g., $\sim 20 \mathrm{mg} \mathrm{kg}^{-1}$ ) tend to foster symbiotic infection rates (Takashasi, 2005). Crop rotation also benefits mycorrhizal association (Ambrosano et al., 2010) with observed 30\% yield increase during three harvests along with increase of sugar content. The plant's genetic inheritance regarding mycorrhization is still elusive, but sugarcane geneticists and physiologists should put efforts in providing tools to enable breeding programs to create genotypes with higher mycorrhization potential, which would certainly have great impact on crop management costs, plant's fitness to adverse conditions and plantation sustainability.

$\mathrm{CO}_{2}$-enriched atmosphere: sugarcane is a $\mathrm{C}_{4}$ plant that evolved specific photosynthetic mechanism to fix $\mathrm{CO}_{2}$. With global climatic changes, many questions have been raised about photosynthetic and water use efficiency in the environment where the $\mathrm{CO}_{2}$ has increased. De Souza et al. (2008) analyzed Brazilian sugarcane varieties grown during 50 weeks under normal (360 ppm) and double $\mathrm{CO}_{2}$ conditions $(720 \mathrm{ppm})$. They observed that plants grown under double $\mathrm{CO}_{2}$ increased photosynthesis by $30 \%$, accumulated $40 \%$ more biomass and had higher water-use efficiency. Microarrays analysis of these plants indicated that 35 genes were differentially expressed on leaves: 14 genes were repressed and 22 genes were induced (De Souza et al., 2008). Moreover, Vu \& Allen (2009) tested two varieties grown also in double $\mathrm{CO}_{2}$ conditions $(720 \mathrm{ppm})$ during 48 weeks and temperature increased by $1.5^{\circ} \mathrm{C}$ or $6.0^{\circ} \mathrm{C}$. They observed that in the double $\mathrm{CO}_{2}$ condition and temperature increase of $6.0^{\circ} \mathrm{C}$, there was an increase of $50 \%$ of leaf area, $26 \%$ increase in leaf dry weight, and $165 \%$ increase in stem juice volume, but the responses were variety specific. The data from both groups showed that sugarcane plants increase productivity under higher $\mathrm{CO}_{2}$ and have better water-use efficiency. 


\section{Breeding strategies and current programs}

\subsection{Breeding methods}

Hybridization (crossing) is the main procedure so far used for sugarcane to generate new genetic recombination events to further perform selection of superior genotypes, focusing on sugar, ethanol or biomass production. The genus Saccharum comprises mainly of six species (S. officinarum, S. robustum, S. spontaneum, S. barberi, S. sinense, and S. edule) that together with other closely related genera, such as Erianthus, Miscanthus, Narenga and Sclerostachya, constitute an inter-breeding group known as the 'Saccharum Complex' (Daniels et al., 1975), which represents the genetic variability pool available for sugarcane breeding.

All around the globe, diverse sugarcane breeding programs developed their own strategies. Briefly, conventional breeding is divided in tree steps: (i) parental selection, (ii) hybridization and, (iii) selection of superior genotypes. The criteria used for parental selection is based on parental value, defined on its potential to generate good progeny. Either biparental or poly-crosses can be used to generate segregating populations. The main advantage of biparental crosses is that the male and female parents are both known, whereas in polycrosses, the exact male parent of the progeny is not readily known, because several pollen sources are placed together to interbreed with only one female. In this case, if a superior genotype is selected, molecular markers can be used to identify the male parent. Although easier to perform, polycrosses are generally considered of lower quality, since it allows predicting only the General Combining Ability (GCA), whereas biparental crosses are more informative for predicting not only the GCA, but also the Specific Combining Ability (SCA) between the parents.

Parental selection and pollination: Crossing and seed production routines involve an inspection of the parental population to verify which genotypes are flowering (visible panicles). Florets are collected and pollen is quantified and tested for viability using iodine staining, to decide which genotype will be used as male, and a pollen fertility scale is made to decide the direction of crosses. Since sugarcane flowers are hermaphrodites, emasculation of the female parent is required to avoid pollen contamination. Heat treatment of the panicle (immersion in water at $50^{\circ} \mathrm{C}$ for $4.5 \mathrm{~min}$ ) is used to eliminate pollen viability of the female parent. The best parental combination is determined using an algorithm that assesses existing database information of each breeding program, considering genetic distance, progeny performance in earlier crosses, and trait complementarity. Flowering stalks of the selected male parent are cut and labeled, transported to the crossing shed, and placed slightly above the female, as pollination occurs by gravity. The set is protected with a 'lantern' to avoid cross-pollination (Fig. 2). The stalks are kept in a nutritive solution, which is replaced frequently to preserve the stalks for about 25 days. After 14 days, the pollination process is complete, and the female stalks are set for another 7-10 days kept in nutrient solution. After the panicles bearing the seeds are dried in a controlled room, at $32^{\circ} \mathrm{C}$ and low humidity for 3 days, the seeds are ready for the next phase - the progeny selection.

Progeny selection: initially, seeds are germinated and the population is screened for traits of high heritability. This phase starts with thousands of plants and those selected are cloned to initiate proper (and recurrent) field experiments (with repetitions), which will be extended for 10-12 years until an elite genotype is released. In the first years, the experiments consist 
of many genotypes (each coming from a single seed) and little material (plants) from each genotype, thus requiring the adoption of experimental designs with small plots, little material from each genotype and a single location, with consequent implications of small experimental precision. As selection advances, the number of genotypes is decreased, allowing the increase of the replication number, plot size, and to include various experimental locations, especially at production environments, thus increasing statistical precision. At later stages, the clones are also evaluated for diverse harvesting time, if the local cropping management system includes more than one harvest a year. The process of clonal selection typically takes $\sim 9$ years to identify the superior genotype, and efforts have been made to increase selection efficiency to reduce the time required to develop a new cultivar. Table 1 summarizes the many steps of a sugarcane selection process with the five basic steps of a sugarcane breeding program.

\subsection{Selection methods}

Individual or bulk selection: the success of a breeding program highly depends on the quality and quantity of genetic variability of the parental population, target trait heritability, and the genetic gain of the trait. According to Dudley \& Moll (1969), the estimation of the genetic variance, genetic co-variance, heritability and the selection gain are fundamental in any plant breeding program, because they allow to answer basic breeding questions: 1) existence of sufficient genetic variability within the available germplasm to allow breeding for a trait of economical importance; 2) estimation of resource usage, including required time, experimental locations, and number of repetitions necessary to test the experimental material; 3) definition of the most efficient and fast method to generate an acceptable gain in the target trait; and 4) assess the method efficiency for simultaneous breeding of all traits being selected. During the seedling phase (P1), in which heritability coefficients of individual plants are low, the selection rate must be high. Therefore, selection of individual plants must be based only on traits with high heritability, such as sugar content measured by brix and disease resistance. Selection for traits of economical importance based on individual plants is usually more efficient when conducted based on family tests.

Family selection: for this approach, whole progenies are completely selected or rejected, according to its mean phenotypic value. Individual values are not considered. Family selection is preferred when the trait under selection presents low heritability, low environmental variation and large families. The efficiency of family selection is based on the deviation shown by environmental effects on each individual that tend to compensate one another. Thus, the mean phenotypic value of each family is close to the mean genotypic value (Falconer \& Mackay, 1996). The number of individuals within a family is an important factor for family selection, because the larger the family, the highest the correlation between mean phenotypic and genotypic values of the family. As noted above, environmental effects are usually high in the first selection phase. For most of the traits of commercial importance, individual selection is ineffective, as $\sim 80 \%$ of the variation is due to environmental factors. However, family selection for these traits might be efficient, since $75-80 \%$ of the phenotypic selection among families is due to genetic factors.

Sequential selection: Family selection efficiency can be enhanced by adding individual selection within the best families (also called selection among and between families). In this case, the selection criterion used within families is based on individual deviation from the mean 


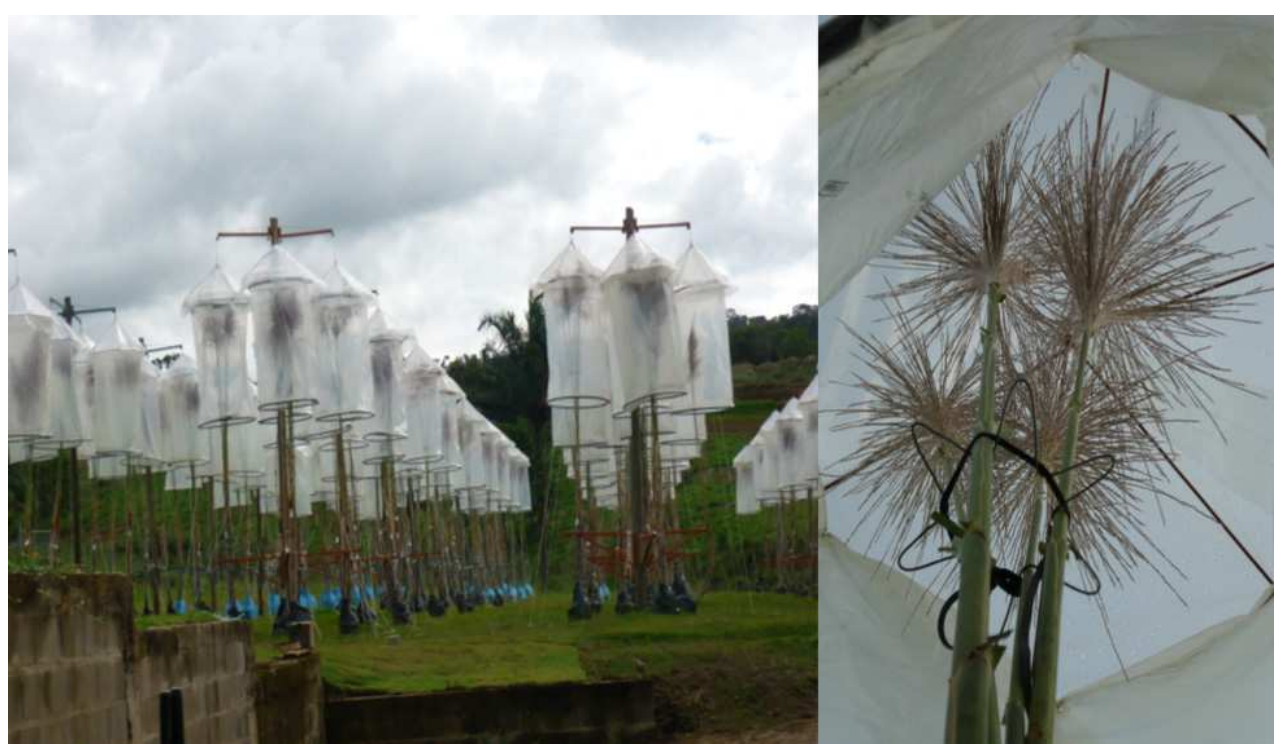

Fig. 2. Sugarcane crossing being carried out under lanterns. Source: Centro de Cana - IAC.

value of its corresponding family (Falconer \& Mackay, 1996). Family selection is only more efficient than individual selection when the heritability based on family means is higher than the heritability of the individual plants. According to McRae et al. (1993) and to Cox et al. (1996), association of family selection with individual selection is more efficient than selection based only on families for sugarcane. Cox \& Hogarth (1993) stated that family selection with repetition of each clone, followed by individual selection within the best family is the most efficient way to select sugarcane.

Regional selection strategy: Besides the methods described above, sugarcane breeding programs have adopted specific strategies for the development of varieties locally adapted to new environments, guiding the hybridization and selection processes as well as establishing regional experimental stations for selection (Landell \& Bressiani, 2008). An important example is the regional selection strategy pioneered by the "Centro de Cana Instituto Agronomico de Campinas", in Brazil, and now adopted by other Brazilian sugarcane breeding programs. This strategy includes a careful characterization of the production environment where seedling populations will be introduced, allowing breeders to isolate important environment factors, favoring the selection of regionally adapted genotypes. Thus, the environment mapping of typical sugarcane cultivation regions is an essential procedure to be considered during hybridization (parental choice) and selection phases. Precise information regarding genotype vs. environment interaction $(G \times E)$ is essential for breeders to define their initial objectives, for example, whether the aim is the development of varieties for a broad range of environments or for a specific environment (Borém, 1998).

\subsection{Performance evaluation}

Complex interaction is the most prominent type of interaction in sugarcane genotype selection, reflected by particular genotype responses to environmental variations. Varietal 


\begin{tabular}{|c|c|c|}
\hline Phases & time & Evaluation \\
\hline $\begin{array}{l}\text { Phase } 1(\mathbf{P 1}) \Rightarrow \text { seedlings: } \\
\text { Individual plants with clumps } \\
\text { spaced } 0.6 \mathrm{~m} \times 1.5 \mathrm{~m} .\end{array}$ & 2 years & $\begin{array}{l}\text { Phenotypic selection for stalk, number, } \\
\text { diameter and height, sugar content, pests } \\
\text { and disease tolerance of plants and ratoon } \\
\text { canes. }\end{array}$ \\
\hline $\begin{array}{l}\text { Phase } 2(\mathbf{P} 2) \Rightarrow \text { clones: } \\
\text { Clones are spaced } 2 \text { (or } 4) \mathrm{m}) \mathrm{x} \\
1.5 \mathrm{~m} .\end{array}$ & 2 years & $\begin{array}{l}\text { Phenotypic selection for stalk number, } \\
\text { diameter and height, sugar content, pests } \\
\text { and disease tolerance of phase } 1 \text { ratoon } \\
\text { canes. Technological evaluation and first } \\
\text { harvest with quantification of yield (tons of } \\
\text { cane per hectare, TCH). }\end{array}$ \\
\hline $\begin{array}{l}\text { Phase } 3(\mathbf{P} 3) \Rightarrow \text { local experiments: } \\
\text { One to two repetitions, with } 30- \\
60 \mathrm{~m} \text { long plots. }\end{array}$ & 1 year & $\begin{array}{l}\text { Phenotypic selection of planted cane for } \\
\text { yield components. }\end{array}$ \\
\hline $\begin{array}{l}\text { Phase } 4(\mathbf{P} 4) \Rightarrow \text { regional experiments: } \\
\text { Plots with } 4-5 \text { lines of } 8-15 \mathrm{~m} \text { long } \\
\text { spaced } 1.1-1.5 \mathrm{~m} \text { from each other, } \\
\text { with randomized block } \\
\text { experimental design ( } 2-4 \\
\text { repetitions in 3-5 locations). }\end{array}$ & 2 years & $\begin{array}{l}\text { Technological evaluation and first cut with } \\
\text { quantification of TPH (tons of pol per } \\
\text { hectare); technological evaluation of second } \\
\text { cut with TPH quantification. Clone selection } \\
\text { for phase } 5 \text {. Cultivation in different locations } \\
\text { in the same region. }\end{array}$ \\
\hline Phase 5 (P5) $\Rightarrow$ final characterization & 4 years & $\begin{array}{l}\text { Technological evaluation of first to fourth cut } \\
\text { with TPH quantification and identification of } \\
\text { superior genotype. }\end{array}$ \\
\hline
\end{tabular}

Table 1. Basic steps of sugarcane selection process (Adapted from Landell \& Bressiani, 2008).

adaptability and stability are other aspects that must be taken into account in breeding programs. Adaptability refers to the variety's capability to take advantage of environmental variations in a positive way. Stability refers to the variety's capability to show a predictable behavior due to environmental changes. There are two main types of stability: static and dynamic. Static stability occurs when a variety has a constant behavior, independently of changes in the environment, and does not show behavior deviations. It is also known as biological stability, and it is more correlated to traits less influenced by environment (qualitative traits), but also sucrose accumulation curve (maturation), and stalk color. On the other hand, dynamic stability, also designated as agronomic stability, is more correlated with quantitative traits. It is characterized when a specific genotype responds to environmental variation in a predictable way. This stability, if well estimated, consists of an important tool for varietal management. Therefore, a promising variety must show high yield and stability in different environmental conditions (Landell \& Bressiani, 2008). Thus, for a good cultivar classification regarding its agronomic potential, it is necessary to associate knowledge about the production environment with individual performance. This way, a cultivar may be classified as: i) stable, when it shows reasonable response to most favorable growing conditions and an average response in non-favorable conditions; ii) responsive, which shows great responses in favorable growing conditions, but does not adapt to more restrictive environments; or iii) rustic or low maintenance cultivar, which, opposite to responsive cultivars, it adapts to more restrictive environments, but does not have top performance in favorable cultivation conditions. 
Among the methods suggested to evaluate the genotypic performance, one of the most traditional methods is analysis of experimental groups. This method considers that a genotype with less variance is also the most stable. However, it is very common that low-variance genotypes also show low yield. Methods based on regression are still widely used, especially because they allow describing individual responses of different genotypes in a group of environments (for more information on selection, see Finlay \& Wilkinsom, 1963; Eberhart \& Russel, 1966; Verma et al., 1978; Duarte \& Vencovsky, 1999).

Regional selection has the advantage to allow a better characterization of a new cultivar, regarding its performance on several yield environments. Studies on phenotypic stability enable one to summarize the huge amount of information obtained from an experimental network, characterizing the yield potential, adaptation to environmental conditions and stability of new cultivars (Raizer \& Vencovsky, 1999). Therefore, new sugarcane cultivars are recommended for specific environments, in association to their specific agricultural management and harvesting period. This strategy allows the breeder to explore the genetic potential of new cultivars at its maximum. In addition to environmental adaptation, another essential aspect in regional selection is the relative importance of yield-related traits. For instance, the ability of a genotype to keep good tillering ability becomes more important in dry areas, which is also an indication of drought tolerance. Other major features for adapting to these particular conditions are ratooning ability (maintenance of stalk number during harvesting cycles) and absence of flowering. The study of production environments provides with a necessary support for identification of a superior genotype, allowing the adoption of suitable crop management strategies. Such strategies must gather heterogeneous environments, including the stratification of equivalent sub-regions, in which the interaction $\mathrm{G} \times \mathrm{E}$ is less significant. The stratification, or agro-ecological zoning, is a very useful procedure, yet having its efficacy restricted due to the occurrence of uncontrollable environmental factors, such as rain and variable thermal amplitude. Notwithstanding, the regional selection strategy has the advantage to enable the identification of a superior genotype in a much shorter period of time ( $\sim 6-7$ years, against $10-12$ years as presented above for traditional selection).

\section{Genetics \& genomics, biotechnology \& molecular biology}

\subsection{Sugarcane genetics - quite a convoluted system}

Sugarcane, Saccharum officinarum $(2 n=70-140)$, also called "noble cane" due to the sweetness of its stalk juice, is a domesticated tropical, perennial grass species (Poaceae family; Andropogoneae tribe). Modern cultivars present a large range in chromosome number $(2 n=100-130)$ and a genome sequence of $\sim 10 \mathrm{~Gb}$ originated from intricate interspecific hybridization, partial loss of chromosomes (aneuploidization), and polyploidization (8-10X) events. Notwithstanding, the basic sugarcane haplotype $(X=10 ; 930 \mathrm{Mb})$ is remarkably small and syntenic to model grasses, such as sorghum.

In China and India, S. officinarum was crossed with $S$. barberi (India cane; $2 n=60-140$ ) and $S$. sinense (China cane; $2 n=104-128$ ) to generate hybrids, the latter thought to be already a hybrid between $S$. officinarum and S. spontaneum $(2 n=36-128)$. During the XIX century, crossings using the wild species $S$. spontaneum $(2 n=36-128)$ were carried out to improve 
sucrose yield and disease resistance (Roach, 1972, 1989). Thus, modern sugarcane cultivars correspond to introgression from the wild species $S$. spontaneum and S. robustum $(2 \mathrm{n}=66-170)$ into the cultivated species S. officinarum, S. sinense and S. barberi (D'Hont et al., 2008, Grivet et al., 2006; Irvine, 1999). S. edule $(2 n=60,70,80)$ is considered ornamental cultivated in New Guinea and Fiji Islands, with no contribution to modern cultivars. Portuguese introduced sugarcane to Brazil during the European colonization period (XV century) probably with hybrids between S. officinarum and S. barberi originated from India and Persia (Daniels \& Daniels, 1975).

Cytogenetics of each species is largely controversial, given methodological difficulties to count such large chromosome number that are confined within a small cell nucleus, or even to establish reliable flow cytometry standards. Molecular genetics is now helping to better understanding the sugarcane origins, because its complex taxonomy has been established based solely on plant morphology and chromosome number. Molecular cytogenetics reveals that $15-25 \%$ of the sugarcane genome is derived from $S$. spontaneum, depending on the genotype. For example, the cultivar R570 has $10 \%$ of chromosomes inherited from $S$. spontaneum, $80 \%$ from S. officinarum and $10 \%$ as a result of recombined chromosomes (D'Hont et al., 2008). Sugarcane is closely related to maize and sorghum. In fact, sugarcane and sorghum shared the last common ancestor only about five million years ago (Paterson et al., 2004), suggesting that sorghum is a good model system to understand the more complex sugarcane biology, as it is diploid and has its genome sequence available (Wang et al., 2010; Paterson et al., 2009). Indeed, the basic sugarcane haplotype (930 Mb) is remarkably syntenic to model grasses, such as sorghum $(730 \mathrm{Mb})$.

\subsection{Molecular markers}

Molecular markers have the potential to speed breeding up, and their main contribution in crops breeding relies on marker-assisted selection (MAS). There are many breeding challenges posed by sugarcane genetics, which consequently affect breeding programs, and so far these have benefit very little of molecular tools generated for sugarcane. The sugarcane genetic map has more than 1,100 molecular markers (considering diverse marker types) with a total map length of 2,600 cM and a marker density of $7.3 \mathrm{cM}$ (Garcia et al., 2006), which is comparable to other crop species (Casu et al., 2005). Molecular markers have been useful to identify and map candidate genes in sugarcane breeding clones (Andru et al., 2011), from DNA regions (Tabasum et al., 2010) as well as from expressed RNA sequences (Wei et al, 2010). Bulked segregant analysis (BSA) coupled with molecular marker analysis of quantitative trait loci has been successful to develop genetic maps around resistance genes in sugarcane against diseases and pests (Asnaghi et al., 2004; Dussle et al., 2003). Molecular markers linked to yield were found in 27 regions of the sugarcane genome from a cross between the Australian variety Q165 and S. officinarum, whereas no significant correlations between stalk traits and sugar yield was found in the population analyzed (Aitken et al., 2008). Also, in a study with 40 sugarcane genotypes including S. officinarum and S. barberi, a high level of polymorphism was detected using 30 random amplification of polymorphic DNA (RAPD) markers, since more than a distinct allele could be identified by each marker (Tabasum et al., 2010). A promising largescale tool may be the diversity array technology (DArT), which can cover the whole-genome to reveal hundreds of thousands of polymorphic markers in a single analysis via high-yield microarray platform (Wei et al., 2010). 
However, sugarcane is a polyaneuploid species, and statistical segregation models have been developed to fit diploid organisms interpretations (Parida et al., 2010; Tabasum et al., 2010; Swapna et al., 2010). About 5\% of publicly available sugarcane unigenes (i.e., assembled expressed sequence tags or ESTs) present single sequence repeats, and the frequency of perfect microsatellites is one marker for every $10.4 \mathrm{~kb}$ (Parida et al., 2010). Considering this, many polymorphic loci obtained during crossings cannot be properly analyzed, given the difficulties due to polyploid segregation (Garcia et al., 2006). In breeding of diploid species, molecular markers are significant for MAS through the use of single nucleotide polymorphisms (SNPs) for polygenic traits such as yield components and disease resistance. Thus, an important aspect of sugarcane breeding is the improvement of markers and statistical models to best fit the convoluted sugarcane genetics (Hotta et al., 2010). The polyploidy constitution of sugarcane makes it as the most difficult crop to apply MAS, that is a sugarcane breeders's dream. Finally, although many available papers report the identification of markers associated with qualitative and quantitative traits in sugarcane, it is noteworthy to mention that they have had very little impact in sugarcane breeding up to now.

\subsection{Functional genomics - transcriptome, proteome and systems biology}

The complex genome of the cultivated sugarcane is currently being sequenced (Sugarcane Genome Sequencing Initiative: http://sugarcanegenome.org), and more effort is supposed to accelerate the discovery of genes responsible for most desirable traits. It will allow the identification of regulatory regions, comparative studies of grasses chromosome, segments evolution and detection of intra and inter-cultivar allelic loci. Transcriptome efforts in sugarcane had a landmark in the late 1990s, when the large-scale cDNA libraries sequencing project SUCEST was set (Vettore et al., 2001, 2003), and from which almost 300,000 EST (ESTs: expressed sequence tags) were obtained, assembled into $\sim 43,000$ unique transcribed sequences, the closest picture of sugarcane transcriptional units. Most functional genomics projects performed in the 1990's focused on sucrose content, disease resistance and stress tolerance, and involved several techniques, such as EST characterization, microarray and SAGE analyses (Vettore et al., 2003; Papini-Terzi et al., 2005; Calsa Jr \& Figueira 2007; Rocha et al., 2007; Menossi et al., 2008; Papini-Terzi et al., 2009; Waclawovsky et al., 2010; Iskandar et al., 2011). The post-genomic era comprises the use of this information into breeding programs, with the identified markers that reveal expression profile of genes in different environmental conditions (Moore, 2005; Waclawovsky et al., 2010; Khan et al., 2011). Although still rather incipient in this crop (Manners \& Casu, 2011), proteomics is increasing its applicability in sugarcane. This was exemplified by recent reports on proteins extraction optimization (Amalraj et al., 2010) and identification of drought tolerance-associated peptides through comparative bi-dimensional electrophoresis followed by mass spectrometry (Ribeiro, 2010). Modern genomics offers the knowledge needed to assign a physiological function to a gene. However, the distance from genotype to phenotype still requires a more integrated approach from molecular data to sugarcane physiology and production, thus setting the basis for modeling the regulatory pathways that link genes, metabolites and physiological processes (Yin \& Struik, 2010).

\subsection{Bacterial artificial chromosome (BAC) library - a useful resource}

Bacterial artificial chromosomes (BAC) clones are bacterial lines containing large chromosome fragments of a particular eukaryotic species of interest. BAC library is a 
collection of these clones that encompass the whole genome of a given species or genotype. These libraries are useful for physical genome sequencing as well as map-based cloning of specific loci or genes. Therefore, these clones are extremely helpful to associate molecular markers closely linked to traits of interest with genome sequences, facilitating identification of the actual genes responsible for the trait. Public BAC collections are available for many crop species, including the sugarcane BAC library at Clemson University Genomics Institute, North Carolina, USA. This library contains $>100,000$ clones of the R570 genotype, each clone with an average insert length of $130 \mathrm{~kb}$, with a genome coverage of $4.5 \mathrm{X}$ and a probability of $98 \%$ of recovering any specific genomic sequence, considering a 3-Gb genome (Tomkins et al., 1999). The availability of BAC libraries of the parental species S. officinarum and $S$. spontaneum as well as a physic map would be extremely useful for the research community to foster sugarcane genetics.

An international effort involving Australia, Brazil, China, France, South Africa and the U.S. has been established to sequence the sugarcane genome. Given the complexity and variability of the sugarcane genome, this is a huge task, but it will be progressed more quickly with the next-generation Illumina or Solid sequencing, and the available sorghum genome. This will facilitate scaffolding efforts given the high synteny between these two species. The data will surely expand our understanding of the sugarcane genome on genomic organization, promoters, gene regulators and gene networks (Hotta et al., 2010), allowing for identification of major players on key agronomical traits.

\subsection{Genetic transformation}

The long time required for conventional breeding of sugarcane and its highly complex genome led to alternative complementary approaches to the to obtain novel or enhanced agronomic traits introduced in commercial hybrids. As mentioned, sugarcane breeding programs usually take 12-15 years to carry out, test and launch a new variety. The transgenic approach using candidate genes for targeted traits is an alternative to significantly shorten breeding time. Sugarcane is a recalcitrant species regarding genetic transformation and several parameters usually need optimization at the variety level to reach higher transformation efficiencies. Genetic transformation of sugarcane first relied on particle bombardment (biolistic) of cell suspension, embryogenic callus or meristem (Bower \& Birch, 1992; Snyman et al., 2006). Efficiency of this method depends on callus formation and plant regeneration, which varies with genotype and culture conditions (Kaeppler et al., 2000). Later, a simpler protocol of genetic transformation of sugarcane using Agrobacterium tumefaciens was developed (Bower \& Birch 1992; Arencibia, 1998; Brumbley et al. 2008). This approach is more efficient than biolistic for its higher stability on transgene expression, which derives from smaller number of transgene copies integrated into the genome (Dai et al. 2001). However, Agrobacterium-mediated transformation shows low efficiency and is highly genotype dependent. For this reason, several in vitro culture parameters have been pointed out as key factors to improve transformation, along with genotype screening, explant type and quality, selective agents, and Agrobacterium strains (Arencibia et al., 1998; Manickavasagam et al., 2004). For sugarcane, the most effective selectable marker is the neomycin phosphotransferase II (nptII) gene (for kanamycin resistance), commonly used to transform callus (Zhangsun et al., 2007; Joyce at al., 2010) that increases the efficiency of transgene integration and recovery of transgenic plants. Specific methodological parameters 
in transformation have not been widely investigated in sugarcane, and this is especially true for direct physical strategies such as biolistic bombardment. In the case of Agrobacteriummediated transformation, efforts have also focused on in vitro regeneration capacity (Joyce et al., 2010).

Genes associated with sucrose content were identified and validated in vivo via genetic transformation, resulted in higher sucrose concentration in transgenic plants (Papini-Terzi et al., 2009). Another important application of genetic transformation is the development of resistance to pests and pathogens, including constructs against bacteria and viruses, as seen after biolistic transformation with the capsid gene of the leaf yellow virus (Arencibia et al., 1997, 1999; Falco et al., 2003; Ingelbrecht \& Mirkov, 1999; Weng et al., 2010). Beyond the use of herbicide resistance genes (e.g., bar and pat) as selective markers, they also confer an attractive trait to reduce production costs (Manickavasagam et al, 2004). Increase in drought tolerance was correlated with proline accumulation in transgenic sugarcane (Molinari et al., 2007). In 2011, EMBRAPA, the Brazilian Company of Agricultural Research, announced the development of a drought-tolerant transgenic containing the transgene DREB2A. This gene codes for a transcription factor that increases the expression of several genes with function in tolerance against heat, drought and salinity.

Despite numerous studies on effective sugarcane transformation, none refers to plastid transformation, although it is a highly promising technology. There are several examples of agronomical/biotechnological applications of plastid transformation with enhanced biosafety (because the transgene is not transmitted via pollen), and higher transgene product yields in dicot species as cotton, soybean, lettuce, carrot, tomato and tobacco (Wang et al, 2009). Chloroplast genetic transformation is still very incipient in $C_{3}$ monocots rice (Lee et al., 2006) and wheat (Cui et al., 2011), and it has not been reported for $C_{4}$ grass species, as sugarcane. However, the avenue is widely open since sugarcane's plastid genome has been completely sequenced (Calsa Jr. et al., 2004), which enables recombination-based transformation, with huge potential for basic and applied research, especially in $\mathrm{C}_{4}$ photosynthesis and molecular pharming. Moreover, the development of transgenic sugarcane for biodegradable polymers, as polyhydroxybutyrate (PHB) is another example of the potential usefulness of this grass, considering its high biomass production (Petrasovits et al., 2007).

Transgenic plants face release restrictions in many countries. The Brazilian Biosafety Commission (CTNBio) has approved more than 40 transgenic crop applications for sugarcane field experiments so far. Field trials are also been conducted in South Africa, Australia, and the U.S., but so far no transgenic variety has been commercially released in Brazil (Cheavegatti-Gianotto et al., 2011).

\subsection{Gene promoters for sugarcane transformation}

The regulation of gene expression involves DNA sequence upstream of the transcribed region and transcription factors that stabilizes RNA polymerases in these promoter regions to start transcription. The availability of useful promoter sequences in crop species enables molecular breeding to coordinate gene expression only in locations where it is necessary and only when it is necessary due to a fine control of place and time of expression. This minimizes pleiotropic effects of a transgene and saves cellular energy that otherwise would unnecessarily transcribe and translate a gene with spending metabolic energy. Although 
many promoters from heterologous species may function similarly in crop species, this opportunity is expected to diminish within evolutionarily more distant species. Thus, a repertoire of gene promoters that work efficiently and precisely regarding level, timing and location of expression is an important element of transgenic cultivar development. Due to the polyploidy nature of sugarcane, the great number of alleles in the same genotype makes promoter isolation difficult, because among the 8-10 alleles, it is difficult to point out which of these are effectively contributing to expression of interesting traits. A recent approach to isolate sugarcane promoters has been published (Damaj et al., 2010). This approach utilizes PCR of BACs. It is important, however, to bear in mind that each BAC holds only a single allele (haplotype) whereas alternative alleles (homoelogous loci) may contain regulatory sequences that diverge from each other.

Thus, despite the convoluted genetic system present in sugarcane, which largely limits the use of traditional genetic markers in breeding programs, it is becoming clear that molecular genetics and genomics will play important roles in sugarcane breeding programs, as transformation techniques become more efficient and more molecular tools (genes of interest, transformation vectors, specific promoters) become available.

\section{Conclusion and perspectives}

Traditionally, the main focus on sugarcane breeding had been on sugar yield. However, recently, a new sugarcane genotype concept is emerging, focusing on biomass production to enable better explore ethanol or energy production. Within this new concept, breeding programs must be reoriented to strengthen its efforts on the development of new cultivars that fit this new variety profile. For this, it is essential to quickly answer to question related to biometrics (stalk number, diameter, height) and processing (sucrose content, reducing sugars, fiber content). Surely, new germplasm resources must be explored by sugarcane breeding programs. The implementation of a parallel introgression program, aiming at broadening the genetic base of sugarcane cultivars for sugar content and/or biomass production, will definitively bring great contributions for increases on yield, ensuring a more sustainable cultivation of sugarcane. Gains on important traits, such as vigor (robustness), will contribute to biomass production and may be found within S. spontaneum accessions and related genera, such as Miscanthus and Erianthus.

New resources and tools are constantly been made available for sugarcane such as better understanding of its genome, genetics, physiology, molecular biology, new markers associated with traits of agronomical relevance and new analysis tools. Breeding programs should take advantage of these tools and incorporate in their selection pipelines to generate superior new cultivars that respond to current and future needs of the industry and the hope of the general society.

\section{Acknowledgments}

Article No. 3111 of the West Virginia Agricultural and Forestry Experiment Station, Morgantown. The authors acknowledge the following funding entities in Brazil: Conselho Nacional de Desenvolvimento Científico e Tecnológico (CNPq), Fundação de Amparo à Pesquisa do Estado de São Paulo (FAPESP), Coordenação de Aperfeiçoamento de Pessoal de Nível Superior (CAPES), Financiadora de Estudos e Projetos (FINEP), Fundação de Amparo 
à Ciência e Tecnologia do Estado de Pernambuco (FACEPE), Ministério de Ciência e Tecnologia (MCT), and Petrobras.

\section{References}

Aitken, K.S.; Hermann, S.; Karno, K.; Bonnett, G.D.; McIntyre, L.C. \& Jackson, P.A. (2008). Genetic Control of Yield Related Stalk Traits in Sugarcane, Theoretical and Applied Genetics, Vol.117, No.7, (November 2008), pp. 1191-1203, ISSN 0040-5752

Amalraj, R.S.; Selvaraj, N.; Veluswamy, G.K.; Ramanujan, R.P.; Muthurajan, R.; Palaniyandi, M.; Agrawal, G.K.; Rakwal, R. \& Viswanathan, R. (2010). Sugarcane Proteomics: Establishment of a Protein Extraction Method for 2-DE in Stalk Tissues and Initiation of Sugarcane Proteome Reference Map. Electrophoresis, Vol.31, No.12, (June 2010), pp. 1959-1974, ISSN 1522-2683.

Ambrosano, E.J.; Azcon, R.; Cantarella, H.; Ambrosano, G.M.B.; Schammass, E.A.; Muraoka, T.; Trivelin, P.C.O.; Rossi, F.; Guirado, N.; Ungaro, M.R.G. \& Teramoto, J.R.S. (2010). Crop Rotation Biomass and Arbuscular Mycorrhizal Fungi Effects on Sugarcane Yield. Scientia Agricola, Vol.67, No.6, (December 2010), pp. 692-701, ISSN 0103-9016

Amorim, H.V; Lopes, M.L.; Oliveira, J.V.C.; Buckeridge, M.S.; Goldman, G.H. (2011). Scientific Challenges of Bioethanol Production in Brazil. Appl. Microbiol. Biotechnol., DOI 10.1007/s00253-011-3437-6, (July 2011), ISSN 0175-7598

Andru, S.; Pan, Y.; Thongthawee, S.;Burner, D. M. \& Kimbeng, C. A. (2011). Genetic Analysis of the Sugarcane (Saccharum spp.) Cultivar 'LCP 85-384'. Linkage Mapping Using AFLP, SSR, and TRAP markers. Theoretical and Applied Genetics, Vol.123, No.1, (June 2011), pp. 77-93, ISSN 0040-5752

Araldi, R.; Silva, F.M.L.; Ono, E.O. \& Rodrigues, D. (2010). Flowering in Sugarcane. Cienc. Rural, Vol.40, No.3, (March 2010), pp. 694-702, ISSN 0103-8478

Arencibia A.; Vazquez, R.I.; Prieto, D.; Tellez, P.; Carmona, E.R.; Coego, A.; Hernandez, L.; Delariva, G.A. \& Selmanhousein G. (1997). Transgenic Sugarcane Plants Resistant to Stem Borer Attack. Mol Breeding, Vol.3, No.4, (August 1997), pp. 247-255, ISSN 1380-3743

Arencibia, A.D.; Carmona, E.R.; Cornide, M.T.; Castiglione, S.; O’Reilly, J.; Chinea, A.; Oramas, P. \& Sala, F. (1999). Somaclonal Variation in Insect-Resistant Transgenic Sugarcane (Saccharum hybrid) Produced by Cell Electroporation. Transgenic Research, Vol.8, No.5, (October 1999), pp. 349-360, ISSN 0962-8819

Arencibia, A.D.; Carmona, E.R.; Tellez, P.; Chan, M.T.; Yu, S.M.; Trujillo, L.E. \& Oramas, P. (1998). An Efficient Protocol for Sugarcane (Saccharum spp. L.) Transformation Mediated by Agrobacterium tumefaciens. Transgenic Research, Vol.7, No.3, (May 1998), pp. 213-222, ISSN 1573-9368

Asnaghi, C.; Roques, D.; Ruffel, S.; Kaye, C.; Hoarau, J.Y.; Télismart, H.; Girard, J.C.; Raboin, L.M.; Risterucci, A.M.; Grivet, L. \& D'Hont, A. (2004). Targeted Mapping of a Sugarcane Rust Resistance Gene (Bru1) Using Bulked Segregant Analysis and AFLP Markers. Theoretical and Applied Genetics, Vol.108, No.4, (February 2004), pp. 759-764, ISSN 0040-5752

Azevedo, J.M. \& Galiana, F.D. (2009). The Sugarcane Ethanol Power Industry in Brazil: Obstacles, Success and Perspectives. IEEE Electrical Power \& Energy Conference 2009, ISBN 9781424445080, Montreal, October 2009 
Bertalan, M.; Albano, R.; Pádua, V. et al. (2009). Complete Genome Sequence of the Sugarcane Nitrogen-Fixing Endophyte Glucoacetobacter diazotrophicus Pal5. BMC Genomics, Vol.10, (September 2009), pp. 450, ISSN 1471-2164

Borém, A. (1998). Melhoramento de plantas (22 edition), Editora UFV, ISBN 85-7269-354-7 Viçosa

Bower, R. \& Birch, R.G. (1992). Transgenic Sugarcane Plants Via Microprojectile Bombardment. Plant Journal, Vol.2, No.3, (May 1992), pp. 409-416, ISSN 0960-7412

Brumbley, S.M.; Snyman, S.J.; Gnanasambandam, A.; Joyce, P.; Hermann, S.R.; da Silva, J.A.G.; McQualter, R.B.; Wang, M.L.; Egan, B.T.; Patterson, A.H.; Albert, H.H. \& Moore, P.H. (2008). Sugarcane. In: Compendium of Transgenic Crop Plants: Transgenic Sugar, Tuber and Fiber Crops, Kole C \& Hall TC (Ed.), 1-58, ISBN 978-1-4051-6924-0, Blackwell, Oxford

Calsa Jr., T. \& Figueira, A. (2007) Serial Analysis of Gene Expression in Sugarcane (Saccharum spp.) Leaves Revealed Alternative C4 Metabolism and Putative Antisense Transcripts. Plant Molecular Biology, Vol.63, No.6, pp. 745-762, ISSN 0735-9640

Calsa Jr., T.; Carraro, D.M.; Benatti, M.R.; Barbosa, A.C.; Kitajima, J.P. \& Carrer, H. (2004) Structural Features and Transcript-editing Analysis of Sugarcane (Saccharum officinarum L.) Chloroplast Genome. Current Genetics, Vol.46, No.6, (December 2004), pp. 366-373, ISSN 0172-8083

Carvalho, L.C.C. (2010). Evolution of Sugarcane Industry in the State of São Paulo, In: Sugar Cane Bioethanol: RED for productivity and sustainability, L.A.B. Cortez, (Ed.), 3-16, Blucher, ISBN: 9788521205302, São Paulo

Castro, O.M. (2010). The role of the State of São Paulo Research Centers on Bioenergy Technological Innovation, In: Sugar Cane Bioethanol: RED for productivity and sustainability, L.A.B. Cortez (Ed.), 63-72, Blucher, ISBN: 9788521205302, São Paulo

Casu, R.; Manners, J.; Bonnett, G.; Jackson, P.; McIntyre, C.; Dunne, R.; Chapman, S.; Rae, A. \& Grof, C. (2005). Genomics Approaches for the Identification of Genes Determining Important Traits in Sugarcane. Field Crops Research, Vol.92, No.2-3, (June 2005), pp. 137-147, ISSN 0378-4290

Cavalcante, V.A. \& Dobereiner, J. (1988). A New Acid-tolerant Nitrogen-fixing Bacterium Associated with Sugarcane. Plant and Soil, Vol.108, No.1, (May 1988), pp. 23-31, ISSN 0032-079X

Cheavegatti-Gianotto, A.; de Abreu, H.M.C.; Arruda, P.; Bespalhok-Filho, J.C.; Burnquist, W.L.; Creste, S.; di Ciero, L.; Ferro, J.A.; Figueira, A.V.O.; Filgueiras, T.S.; Grossi-deSá, M.F.; Guzzo, E.C.; Hoffmann, H.P.; Landell, M.G.A.; Macedo, N.; Matsuoka, S.; Reinach, F.C.; Romano, E.; da Silva, W.J.; Silva-Filho, M.C. \& Ulian, E.C. (2011). Sugarcane (Saccharum X officinarum): A Reference Study for the Regulation of Genetically Modified Cultivars in Brazil. Tropical Plant Biol., Vol.4, (February 2001), pp. 62-89, ISSN 1935-9756

Clements, H.F. \& Awada, M. (1967). Experiments on the Artificial Induction of Flowering in Sugarcane. Proc. Int. Soc. Sugarcane. Technol., Vol.12, No.1, pp.795 - 812, 1967

Contreras, A.M.; Rosa, E.; Pérez, M.; van Langenhove, H. \& Dewulf, J. (2009). Comparative Life Cycle Assessment of Four Alternatives for Using By-products of Cane Sugar Production. Journal of Cleaner Production, Vol.17, No.8, (May 2009), pp. 772-779, 0959-6526

Cortez, L.A.B. (2010). Introduction, In: Sugar Cane Bioethanol: RED for productivity and sustainability, L.A.B. Cortez, (Ed.), 3-16, Blucher, ISBN: 9788521205302, São Paulo 
Cox, M.C. \& Hogarth, D.M. (1993). The Effectiveness of Family Selection in Early Stages of a Sugarcane Improvement Program. Australian Plant Breeding Conference, Vol. 10, pp. 53-54, ISBN 1864239573, Bundaberg, Brisbane: Watson Ferguson, April 1993

Cox, M.C.; Mcrae, T.A.; Bull, J.K. \& Hogarth, D.M. (1996). Family Selection Improves the Efficiency and Effectiveness of a Sugarcane Improvement Program. In: Sugarcane: research towards efficient and sustainable production. J.R. Wilson; D.M. Hogarth; J.A. Campbell \& A.L. Garside, (Ed.), 42-43, Brisbane: CSIRO Division of Tropical Crops and Pasture, ISBN 0643059415, Australia

Creste, S.; Pinto, L.R.; Xavier, M.A. \& Landell, M.G.A. (2010). Sugarcane Breeding Method and Genetic Mapping, In: Sugar Cane Bioethanol: RED for productivity and sustainability, L.A.B. Cortez (Ed.), 353-357, Blucher, ISBN: 9788521205302, São Paulo

Cui, C.; Song, F.; Tan, Y.; Zhou, X.; Zhao, W.; Ma, F.; Liu, Y.; Hussain, J.; Wang, Y.; Yang, G. \& He, G. (2011). Stable Chloroplast Transformation of Immature Scutella and Inflorescences in Wheat (Triticum aestivum L.). Acta Biochimica et Biophysica Sinica (Shanghai), Vol.43, No.4, (April 2011), pp. 284-291, ISSN 1672-9145

D’Hont, A.; Souza, G.M.; Menossi, M.; Vincentz, M.; Van Sluys, M.A.; Glaszmann, J.C. \& Ulian, E. (2008). Sugarcane: A major Source of Sweetness, Alcohol, and Bio-energy, In: Genomics of Tropical Crop Plants, P.H. Moore \& R. Ming, (Ed.), 483-513, Springer, ISBN: 9781441924339, New York

Dai, S.H.; Zheng, P.; Marmey, P.; Zhang, S.P.; Tian, W.Z.; Chen, S.Y.; Beachy, R.N. \& Fauquet, C. (2001). Comparative Analysis of Transgenic Rice Plants Obtained by Agrobacterium Mediated Transformation and Particle Bombardment. Molecular Breeding, Vol.7, No.1, (January 2001), pp. 25-33, ISSN 1380-3743

Damaj, M.B.; Beremand, P.D.; Buenrostro-Nava, M.T.; Ivy, J.; Kumpatla, S.P.; Jifon, J.; Beyene, G.; Yu, Q.; Thomas, T.L. \& Mirkov, T.E. (2010). Isolating Promoters of Multigene Family Members from the Polyploid Sugarcane Genome by PCR-based Walking in BAC DNA. Genome, Vol.53, No.10, (October 2010), pp. 840-847, ISSN 0831-2796

Daniels, J. \& Daniels C.A. (1975). Geographical, Historical and Cultural Aspects of the Origin of the Indian and Chinese Sugarcanes S. barberi and S. sinense. Sugarcane Breeding Newsletters, Vol. 36, pp. 4-23, ISSN 1028-1193

Daniels, J. \& Roach, B.T. (1987). Taxonomy and Evolution, In: Sugarcane Improvement through Breeding, D. J. Heinz (Ed.), 7-84, Elsevier, ISBN: 0444427694, Amsterdam

Daniels, J.; Smith, P.; Paton, N. \& Williams, C.A. (1975). The Origin of the Genus Saccharum. Sugarcane Breeding Newsletter, Vol. 36, 24-39, ISSN 1028-1193

de Souza, A.P.; Gaspar, M.; Da Silva, E.A.; Ulian, U.C.; Waclawovsky, A.J.; Nishiyama Jr., M.Y.; Santos, R.V.; Teixeira, M.M.; Souza, G.M. \& Buckeridge, M.S. (2008). Elevated $\mathrm{CO}_{2}$ Increases Photosynthesis, Biomass and Productivity, and Modifies Gene Expression in Sugarcane. Plant, Cell and Environment, Vol.31, No.8, (August 2008), pp. 1116-1127, ISSN 0140-7791

Duarte, J.B. \& Vencovsky, R. (1999). Interação Genótipos x Ambientes: Uma Introdução à Análise AMMI. (9 edition), Sociedade Brasileira de Genética, ISBN 85-85572-79-5, Ribeirão Preto

Dudley, J.W. \& Moll, R.H. (1969). Interpretation and Use of Estimates of Heritability and Genetic Variances in Plant Breeding. Crop Science, Vol.9, No.3, (July 1969), pp. 257262, ISSN 0011-183X 
Dussle, C.M.; Quint, M.; Melchinger, A.E.; Xu, M.L. \& Lübberstedt, T. (2003). Saturation of Two Chromosome Regions Conferring Resistance to SCMV with SSR and AFLP Markers by Targeted BSA. Theoretical and Applied Genetics, Vol.106, No.3, (February 2003), pp. 485-493, ISSN 0040-5752

Eberhart, S.A. \& Russel, W.A. (1966). Stability Parameters for Comparing Varieties. Crop Science, Vol.1, No.5, (July 1966), pp. 36-40, ISSN 0011-183X

Erisman, J.W.; Sutton, M.A.; Galloway, J.; Klimont, Z. \& Winiwarter, W. (2008). How a Century of Ammonia Synthesis Changed the World. Nature Geoscience, Vol.1, (September 2008), pp. 636-639, ISSN 1752-0894

Falco, M.C. \& Silva-Filho, M.C. (2003). Expression of Soybean Proteinase Inhibitors in Transgenic Sugarcane Plants: Effects on Natural Defense Against Diatraea saccharalis. Plant Physiology and Biochemistry, Vol.41, No.8, (August 2003), pp 761766, ISSN 0981-9428

Falconer, D.S. \& Mackay, T.F.C. (1996). Introduction to Quantitative Genetics (4th ed.), Longman, ISBN 9780582243026, London

Finlay, K. W. \& Wilkinson, G. N. (1963). The Analysis of Adaptation in a Plant Breeding Programme. Australian Journal of Agricultural Research, Vol. 14, No.6, (June 1963), pp. 742-754, ISSN 0004-9409

Garcia, A.A.; Kido, E.A.; Meza, A.N.; Souza, H.M.; Pinto, L.R.; Pastina, M.M.; Leite, C.S.; Silva, J.A.; Ulian, E.C.; Figueira, A. \& Souza, A.P. (2006). Development of an Integrated Genetic Map of a Sugarcane (Saccharum spp.) Commercial Cross, Based on a Maximum-Likelihood Approach for Estimation of Linkage and Linkage Phases. Theorical and Applied Genetics, Vol.112, No.2, (January 2006), pp. 298-314, ISSN 0040-5752

Gazaffi, R.; Oliveira, K.M.; Souza, A.P. \& Garcia, A.A.F. (2010). The Importance of the Germoplasm in Developing Agro-Energetic Profile Sugarcane Cultivars, In: Sugar Cane Bioethanol: RED for productivity and sustainability, L.A.B. Cortez (Ed.), 333-343, Blucher, ISBN: 9788521205302, São Paulo

Giller, K. E. (2001). Nitrogen Fixation in Tropical Cropping Systems (2nd ed.), CABI Publishing, ISBN 0851994172, Oxon, U.K.

Goldemberg, J. (2008). The Brazilian Biofuels Industry. Biotechnology for Biofuels, Vol.1, No.6, (May 2008), pp. 1-7, ISSN 1754-6834

Goldemberg, J. (2010). The State of São Paulo Strategy for Fuel Ethanol, In: Sugar Cane Bioethanol: RED for productivity and sustainability, L.A.B. Cortez (Ed.), 19-26, Blucher, ISBN: 9788521205302, São Paulo

Goldemberg, J.; Coelho, S.T. \& Guardabassi, P. (2008). The Sustainability of Ethanol Production from Sugarcane. Energy Policy, Vol.36, (April 2008), pp. 1086-2097, ISSN 0301-4215

Gonçalves, H.M.; Borges, J.D. \& da Silva, M.A.S. (2009). Heavy Metals and Sulphur Accumulation on Soil in Areas of Influence of Vinasse Channels of Fertilization. Bioscience Journal, Vol.25, No.6, (November-December 2009), pp. 66-74, ISSN 1516-3725

Grad, P. (2006). Biofuelling Brazil: An Overview of the Bioethanol Success Story in Brazil. Refocus, Vol.7, No.3, (May-June 2006), pp. 56-59, ISBN 1471-0846

Grivet, L.; Glaszmann, J.C. \& D’Hont, A. (2006). Molecular Evidence for Sugarcane Evolution and Domestication, In: Darwin's Harvest. New Approaches to the Origins, 
Evolution and Conservation. T. Moley; N. Zerega \& H. Cross (Eds), 49-66, Columbia University Press, ISBN 9780231133166, West Sussex, UK

Hawker, J. S. (1965). The Sugar Content of Cell Walls and Intercellular Spaces in Surgarcane Stems and its Relation to Sugar Transport. Australian Journal of Biological Sciences, Vol.18, No.5, (May 1965), pp. 959-969, ISSN 0004-9417

Henniges, O. \& Zeddies, J. (2004). Competiveness of Brazilian Ethanol in the EU. FO Litch's World Ethanol and Biofuels Report, Vol. 2, pp. 374-378, ISSN 1478-5765

Hill, J.; Nelson, E.; Tilman, D.; Polasky, S. \& Tiffany, D. (2006). Environmental, Economic, and Energetic Costs and Benefits of Biodiesel and Ethanol Biofuels. Proceeding of the National Academy of Sciences U.S.A., Vol.103, No.30, (July 2006), pp. 11206-11210, ISSN 0027-8424

Hobhouse, H. (2005). Seeds of Change: six plants that transformed mankind. Counterpoint, ISBN 978-1593760496, Berkeley, CA

Hotta, C.T.; Lembke, C.G.; Domingues, D.S.; Ochoa, E.A.; Cruz, G.M.Q.; Melotto-Passarin, D.; Marconi, T.G.; Santos, M.O.; Mollinari, M.; Margarido, G.R.A.; Crivellari, A.C.; Santos, W.D.; Souza, A.P.; Hoshino, A.A.; Carrer, H.; Souza, A.P.; Garcia, A.A.F.; Buckeridge, M.S.; Menossi, M.; Van Sluys, M.A. \& Souza, G.M. (2010). The Biotecnological Roadmap for Sugarcane Improvement. Tropical Plant Biology, Vol.3, No.2, (April 2010), pp. 75-87, ISSN 1935-9756

Ingelbrecht, I.L.; Irvine, J.E. \& Mirkov, T.E. (1999). Posttranscriptional Gene Silencing in Transgenic Sugarcane. Dissection of Homology-Dependent Virus Resistance in a Monocot That Has a Complex Polyploid Genome. Plant Physiology, Vol.119, No.4, (April 1999), pp. 1187-1198, ISSN 0032-0889

Innan-Bamber, N.G. \& Smith, D.M. (2005). Water Relations in Sugarcane and Response to Water Deficits. Field Crops Research, Vol.92, No.2-3, (June 2005), pp. 185-202, ISSN 0378-4290

Irvine, J.E. (1999). Saccharum Species as Horticultural Classes. Theoretical and Applied Genetics, Vol.98, No.2, (February 1999), pp. 186-194, ISSN 0040-5752

Iskandar, H.M.; Casu, R.E.; Fletcher, A.T.; Schmidt, S.; Xu, J.; Maclean, D.J.; Manners, J.M. \& Bonnett, G.D. (2011). Identification of Drought Response Genes and a Study of Their Expression During Sucrose Accumulation and Water Deficit in Sugarcane Culms. BMC Plant Biology, Vol.11, (January 2011), pp. 12, ISSN 1471-2229

Jackson, P.A. (2005). Breeding for Improved Sugar Content in Sugarcane. Field Crops Research, Vol.92, No.2-3, (June 2005), pp. 277-290, ISSN 0378-4290

Joyce, P.; Kuwahata, M.; Turner, N. \& Lakshmanan, P. (2010). Selection System and CoCultivation Medium are Important Determinants of Agrobacterium Mediated Transformation of Sugarcane. Plant Cell Reports, Vol.29, No.2, (February 2010), pp. 173-183, ISSN 0721-7714

Kaeppler, S.M.; Kaeppler, H.F. \& Rhee, Y. (2000). Epigenetic Aspects of Somaclonal Variation in Plants. Plant Molecular Biology, Vol.43, No.2-3, (June 2000), pp. 179-188, ISSN 0735-9640

Khan, M. S.; Yadav,S.; Srivastava,S.; Swapna, M.; Chandra, A. \& Singh, R. K. (2011). Development and Utilization of Conserved Intron Scanning Marker in Sugarcane. Australian Journal of Botany, Vol.59, No.1, (February 2011), pp. 38-45, ISSN 0067-1924

Kirch, H.H.; Schlingensiepen, S.; Kotchoni, S.; Sunkar, R. \& Bartels, D. (2005). Detailed Expression Analysis of Selected Genes of the Aldehyde Dehydrogenase (ALDH) Gene 
Superfamily in Arabidopsis thaliana. Plant Mol Biol., Vol.57, No.3, (February 2005), pp. 315-332, ISSN 0735-9640

Koizumi, M.; Yamaguchi-Shinozaki, K., Tsuji, H. \& Shinozaki, K. (1993). Structure and Expression of Two Genes That Encode Distinct Drought-Inducible Cysteine Proteinases in Arabidopsis thaliana. Gene, Vol.129, No.2, (July 1993), pp. 175-182, ISSN 0378-1119

Lam, E.; Shine, J.; Silva, J. da; Lawton, M.; Bonoss, S.; Calvino, M.; Carrer, H.; Silva-Filho, M.; Glynn, N.; Helsels, Z.; Ma, J.; Richard, E.; Souza, G.M. \& Ming, R. (2009). Improving Sugarcane for Biofuel: Engineering for an Even Better Feedstock. GCB Bioenergy, Vol.1, (July 2009), pp. 251-255, ISSN 1557-1693

Landell, M. (2003). ProCana - O Programa Cana-de-açúcar do Instituto Agronômico. O Agronomico, Vol.55, No.1, pp. 5-8, ISSN 0365-2726

Landell, M.G.A. \& Bressiani, J.A. (2008). Melhoramento Genético, Caracterização e Manejo Varietal. In: Cana-de-açúcar. Dinardo-Miranda, L.L.; Vasconcelos, A.C.M.; Landell, M.G.A. (Eds.), 101 - 155, Instituto Agronômico, ISBN 9788585564179, Campinas

Landell, M.G.A.; Creste, S.; Pinto, L.R.; Xavier, M.A. \& Bressiani, J.A. (2010). The Strategy For Regional Selection For The Development of Energy Sugarcane Cultivar Profile. In: Sugar Cane Bioethanol: RED for productivity and sustainability L.A.B. Cortez (Ed.), 345-352, Blucher, ISBN: 9788521205302, São Paulo

Lee, S.M.; Kang, K.; Chung, H.; Yoo, S.H.; Xu, X.M.; Lee, S.B.; Cheong, J.J.; Daniell, H. \& Kim, M. (2006). Plastid Transformation in the Monocotyledonous Cereal Crop, Rice (Oryza sativa) and Transmission of Transgenes to Their Progeny. Molecular Cells, Vol.21, No.3, (June 2006), pp. 401-410, ISSN 1097-2765

Leite, R.C.C. (2010). The Brazilian Strategy for Bioethanol, In: Sugar Cane Bioethanol: RED for productivity and sustainability, L.A.B. Cortez, (Ed.), 17-18, Blucher, ISBN 9788521205302, São Paulo

Leite, R.C.C.; Leal, M.R.L.V.; Cortez, L.A.B.; Griffin, W.M. \& Scandiffio, M.I.G. (2009). Can Brazil Replace 5\% of the 2025 Gasoline World Demand With Ethanol? Energy, Vol.34, pp. 655-661, ISSN 0360-5442

Liu, G.F.; Zhou, H.K.; Zhu, Z.H.; Xu, H.M. \& Yang, J. (2007). Genetic Analysis for Brix Weight per Stool and Its Component Traits in Sugarcane (Saccharum officinarum). Journal of Zheijang University Science B, Vol.8, No.12, (December 2007), pp. 860-866, ISSN 1673-1581

Lora, E.S. \& Andrade, R.V. (2009). Biomass As Energy Source in Brazil. Renewable and Sustainable Energy Reviews, Vol.13, No.4, (May 2009), pp. 777-788, ISSN 1364-0321

Manickavasagam, M.; Ganapathi, A.; Anbazhagan, V.R.; Sudhakar, B.; Selvaraj, N.; Vasudevan, A. \& Kasthurirengan, S. (2004). Agrobacterium Mediated Genetic Transformation and Development of Herbicide-Resistant Sugarcane (Saccharum species hybrids) Using Axillary Buds. Plant Cell Reports, Vol.23, No.3, (September 2004), pp. 134-143, ISSN 0721-7714

Manners, J.M \& Casu, R.E. (2011) Transcriptome Analysis and Functional Genomics of Sugarcane. Tropical Plant Biology, Vol.4, No.1, (March 2011), pp. 9-21, ISSN 1935-9756

Martinelli, L.A. \& Filoso, L. (2008). Expansion of Sugarcane Ethanol Production in Brazil: Environmental and Social Challenges. Ecological Applications, Vol.18, No.4, (April 2008), pp. 885-898, ISSN 1051-0761 
McRae, T.A.; Hogath, D.M.; Foreman, J.W. \& Braithwaite, M.J. (1993). Selection of Sugarcane Seedling Families in Burdekin District, Australian Plant Breeding Conference, Vol. 1, pp. 77-82, ISBN 0646134361, Gold Coast, Australia, April 1993

Melo, L.C.P. \& Poppe, M.K. (2010). Challenges in Research, Development and Innovation in Biofuels in Brazil, In: Sugar Cane Bioethanol: RED for productivity and sustainability L.A.B. Cortez (Ed.), 27-34, Blucher, ISBN: 9788521205302, São Paulo

Menossi, M.; Silva-Filho M.C.; Vincentz, M.; Van-Sluys, M.A. \& Souza, G.M. (2008). Sugarcane Functional Genomics: Gene Discovery for Agronomic Trait Development. International Journal of Plant Genomics, Vol.2008, (December 2007), pp. 458732, ISSN 16875370

Milligan, S.B.; Gravois, K.A.; Bischoff, K.P. \& Martin, F.A. (1990). Crop Effects on Genetic Relationships Among Sugarcane Traits. Crop Science, Vol.30, No.4, (April 2004), pp. 927-931, ISSN 0011-183X

Miranda, E.E. (2010). Environmental (Local and Global) Impact and Energy Issues on Sugarcane Expansion and Land Occupation in the São Paulo State, In: Sugar Cane Bioethanol: RED for productivity and sustainability L.A.B. Cortez (Ed.), 41-52, Blucher, ISBN: 9788521205302, São Paulo

Molinari, H.B.C.; Marur, C.J.; Daros, E.; Campos, M.K.F.; Carvalho, J.F.R.P.; BespalhokFilho, J.C.; Pereira, L.F.P. \& Vieira, L.G.E. (2007). Evaluation of the Stress-Inducible Production of 6-proline in Transgenic Sugarcane (Saccharum spp.): Osmotic Adjustment, Chlorophyll Fluorescence and Oxidative Stress. Physiologia Plantarum, Vol.130, No.2, (June 2007), pp. 218-229, ISSN 0031-9317

Moore, P. H. (2005). Integration of Sucrose Accumulation Processes Across Hierarchical Scales: Towards Developing an Understanding of the Gene-to-Crop Continuum. Field Crops Research, Vol.92, pp. 119-135, ISSN 0378-4290

Moore, P.H. \& Nuss, K.J. (1987). Flowering and Flower Synchronization. In: Sugarcane improvement through breeding, Heinz, D.J. (Ed), 273-311, Elsevier, ISBN 0444427694, Amsterdam.

Nass, L.L.; Pereira, P.A.A., \& Ellis, D. (2007). Biofuels in Brazil: An overview. Crop Science, Vol.47, (November-December 2007), pp. 2228-2237, ISSN 0931-2250

Pandey, A.; Soccol, C.R.; Nigam, P. \& Soccol, V.T. (2000). Biotecnological Potential of AgroIndustrial Residues. I: Sugarcane Bagasse. Bioresource Tecnhology, Vol.74, No.1, (August 2000), pp. 69-80, ISSN 0960-8524

Papini-Terzi, F. S.; Rocha, F. R.; Vêncio, R. Z. N.; Felix, J. M.; Branco, D. S.; Waclawovsky, A. J.; Del Bem, L. E. V.; Lembke, C. G.; Costa, M. D. L.; Nishiyama Jr, M. Y.; Vicentini, R.; Vincentz, M. G. A.; Ulian, E. C.; Menossi, M. \& Souza, G. M. (2009). Sugarcane Genes Associated with Sucrose Contente. BMC Genomics, Vol.10, No.120, (March 2009), pp. 120, ISSN 1471-2164

Papini-Terzi, F.S.; Rocha, F.R.; Vêncio, R.Z.; Oliveira, K.C.; Felix, J. de M.; Vicentini, R.; Rocha, C. de S.; Simões, A.C.; Ulian, E.C.; di Mauro, S.M.; da Silva, A.M.; Pereira, C.A.; Menossi, M. \& Souza, G.M. (2005). Transcription Profiling of Signal Transduction-Related Genes in Sugarcane Tissues. DNA Research, Vol.12, No.1, (January 2005), pp. 27-38, ISSN 1340-2838

Parida, S.K.; Pandit, A.; Gaikwad, K.; Sharma, T.R.; Srivastava, P.S.; Singh, N.K. \& Mohapatra, T. (2010). Functionally Relevant Microsatellites in Sugarcane Unigenes. BMC Plant Biology, Vol.10, (November 2010), pp. 251, ISSN 1471-2229 
Paterson, A.H., Bowers, J.E. \& Chapman, B.A. (2004) Ancient Polyploidization Predating Divergence of the Cereals, And Its Consequences For Comparative Genomics. Proc. Natl. Acad. Sci. USA Vol.101, No.26, (June 2004), pp. 9903-9908, ISSN 0027-8424

Paterson, A.H.; Bowers, J.E. et al. (2009). The Sorghum bicolor Genome and the Diversification of Grasses. Nature, Vol.457, (January 2009), pp. 551-556, ISSN 0028-0836

Petrasovits, L.A.; Purnell, M.P.; Nielsen, L.K. \& Brumbley, S.M. (2007). Production of Polyhydroxybutyrate in Sugarcane. Plant Biotechnology Journal, Vol.5, No.1, (January 2007), pp. 162-172, ISSN 1467-7644

Rabbani, M.A.; Maruyama, K.; Abe, H.; Khan, M.A.; Katsura, K.; Ito, Y.; Yoshiwara, K.; Seki, M.; Shinozaki K. \& Yamaguchi-Shinozaki, K. (2003). Monitoring Expression Profiles of Rice (Oryza sativa L.) Genes Under Cold, Drought and High-Salinity Stresses, and ABA Application Using Both cDNA Microarray and RNA Gel Blot Analyses. Plant Physiology, Vol.133, No.4, (December 2003), pp. 1755-1767, ISSN 0032-0889

Ragauskas, A.J.; Williams, C.K.; Davison, B.H.; Britovsek, G.; Cairney, J.; Eckert, C.K.; Frederick Jr., W.J.; Hallett, J.P.; Leak, D.J.; Liotta, C.L.; Mielenz, J.R.; Murphey, R.; Templer, R. \& Tschaplinski, T. (2006). The Path Forward for Biofuels and Biomaterials. Science, Vol.311, (January 2006), pp. 484-489, ISSN 0036-8075

Raizer, A.J. \& Vencovsky, R. (1999). Estabilidade Fenotípica de Novas Variedades de Canade-Açúcar para o Estado de São Paulo. Pesquisa Agropecuária Brasileira, Vol.34, No.12, pp. 2241-2246, ISSN 0100-204X

Reis, V.M.; de Paula, M.A. \& Döbereiner, J. (1999) Ocorrência de Micorrizas Arbusculares e da Bactéria Diazotrófica Acetobacter diazotrophicus em Cana-de-açúcar. Pesquisa Agropecuária Brasileir, Vol.34, No.7, (Julho 1999), pp. 1933-1941, ISSN 0100-204X

Ribeiro, I.L.A.C. (2010) Proteômica de cana-de-açúcar em condição de estresse hídrico. Dissertation. Universidade Federal de Pernambuco, Recife, Brasil. 127 p.

Ripoli, T.C.C.; Molina Jr., W.F. \& Ripoli, M.L.C. (2000). Energy Potential of Sugarcane Biomass in Brazil. Scientia Agricola, Vol.57, No.4, (October-November 2000), pp. 677-681, ISSN 0103-9016

Roach, B.T. (1972). Nobilisation of sugarcane. Proc. Int. Soc. Sugarcane. Technol., Vol.14, pp. 206-216

Roach, B.T. (1989). Origin and Improvement of the Genetic Base of Sugarcane. XX Proc. Int. Soc. Sugarcane. Technol., Vol. 11, pp. 35-47, São Paulo, 1989

Rocha, F.R.; Papini-Terzi, F.S.; Nishiyama Jr., M.Y.; Vêncio, R.Z.; Vicentini, R.; Duarte, R.D.; de Rosa Jr., V.E.; Vinagre, F.; Barsalobres, C.; Medeiros, A.H.; Rodrigues, F.A.; Ulian, E.C.; Zingaretti, S.M.; Galbiatti, J.A.; Almeida, R.S.; Figueira, A.V.; Hemerly, A.S.; Silva-Filho, M.C.; Menossi, M. \& Souza, G.M. (2007). Signal Transduction Rlated Responses to Phytohormones and Environmental Challenges in Sugarcane. BMC Genomics, Vol.8, (March 2007), pp. 71, ISSN 1471-2164

Rogers, T.D. (2010). The Deepest Wounds: A Labor and Environmental History of Sugar in Northeast Brazil. University of North Carolina Press, ISBN 978-0807871676, Chapel Hill, NC

Seki, M.; Ishida, J.; Narusaka, M.; Fujita, M.; Nanjo, T.; Umezawa, T.; Kamiya, A.; Nakajima, M.; Enju, A.; Sakurai, T.; Satou, M.; Akiyama, K.; Yamaguchi-Shinozaki, K.; Carninci, P.; Kawai, J.; Hayashizaki, Y. \& Shinozaki, K. (2002). Monitoring the expression pattern of around 7,000 Arabidopsis genes under ABA treatments using a full-length cDNA microarray. Funct Integr Genomics, Vol.2, No.6, (November 2002), pp. 282-291, ISSN 1438-793X 
Seki, M.; Narusaka M.; Abe, H.; Kasuga M.; Yamaguchi-Shinozaki, K.; Carninci, P.; Hayashizaki, Y. \& Shinozaki, K. (2001). Monitoring the Expression Pattern of 1300 Arabidopsis Genes Under Drought and Cold Stresses by Using a Full-Length cDNA Microarray. The Plant Cell, Vol.13, No.1, (January 2001), pp. 61-72, ISSN 1040-4651

Singels, A.; Smit, M.A.; Redshaw, K.A. \& Donaldson, R.A. (2005). The Effect of Crop Start Date, Crop Class and Cultivar on Sugarcane Canopy Development and Radiation Interception. Field Crops Research, Vol.92, No.2-3, (June 2005), pp. 249-260, ISSN 0378-4290

Snyman, S.J.; Meyer, G.M.; Richards, J.M.; Haricharan N.; Ramgareeb, S. \& Huckett, B.I. (2006). Refining The Application of Direct Embryogenesis In Sugarcane: Effect of the Developmental Phase of Leaf Disc Explants and the Timing of DNA Transfer on Transformation Efficiency. Plant Cell Rep, Vol.25, No.10, (October 2006), pp. 1016-1023, ISSN 0721-7714

Swapna, M.; Sivaraju, K.; Sharma, R. K.; Singh, N. K. \& Mohapatra, T. (2010). Single-Strand Conformational Polymorphism of EST-SSRs: a Potential Tool for Diversity Analysis and Varietal Identification in Sugarcane. Plant Molecular Biology Reports, Vol.5, pp. 254-263, ISSN 0735-9640

Tabasum, S.; Khan, F.A.; Nawaz, S.; Iqbal, M.Z. \& Saeed, A. (2010). DNA Profiling of Sugarcane Genotypes Using Randomly Amplified Polymorphic DNA. Genetics and Molecular Research, Vol.9, No.1, pp. 471-483, ISSN 1676-5680

Thaweenut, N.; Hachisuba, Y.; Ando, S.; Yanagisawa, S. \& Yoneyama, T. (2011). Two Seasons Study of nifH Gene Expression and Nitrogen Fixation by Fiazotrophic Fndophytes in Sugarcane (Saccharum spp. hybrids): Expression of nifH Genes Similar to Those of Rhizobia. Plant and Soil, Vol.338, No.1-2, (January 2011), pp. 435449, ISBN 0032-079X

Tomkins, J.P.; Yu, Y.; Miller-Smith, H.; Frisch, D.A.; Woo, S.S. \& Wing, R.A. (1999). A Bacterial Artificial Chromosome Library for Sugarcane. Theoretical and Applied Genetics, Vol.99, No.3-4, (August 1999), pp. 419-424, ISSN 0040-5752

Tran, L.S.P.; Nakashima, K.; Sakuma, Y.; Simpson, S.D.; Fujita, Y.; Maruyama, K.; Fujita, M.; Seki, M.; Shinozaki, K. \& Yamaguchi-Shinozaki, K. (2004). Isolation and Functional Analysis of Arabidopsis Stress-Inducible NAC Transcription Factors That Bind to a Drought-Responsive Cis-Element in The Early Responsive to Dehydration Stress 1 Promoter. The Plant Cell, Vol.16, No.9, (September 2009), pp. 2481-2498, ISSN 10404651

Uriarte, M.; Yackulic, C.B.; Cooper, T.; Flynn, D.; Cortes, M.; Crk, T.; Cullman, G.; McGinty, M. \& Sircely, J. (2009). Expansion of Sugarcane Production in São Paulo, Brazil: Implications For Fire Occurrence and Respiratory Health. Agriculture Ecosystems $\mathcal{E}$ Environment, Vol.132, No.1-2, (Julho 2009), pp. 48-56, ISSN 0167-8809

Vega-Sánchez, M.E. \& Ronald P.C. (2010). Genetic and Biotechnological Approaches for Biofuel Crop Improvement. Current Opinion in Biotechnology, Vol.21, No.2, (February 2010), pp. 218-224, ISSN 0958-1669

Verma, M.M.; Chahal, G.S. \& Murty, B.R. (1978). Limitations of Conventional Regression Analysis: a Proposed Modifications. Theoretical and Applied Genetics, Vol. 53, No.2, (March 1978), pp. 89-91, ISSN 0040-5752

Vettore, A.L.; da Silva, F.R.; Kemper, E.L. \& Arruda, P. (2001). The Libraries That Made SUCEST. Genetic Molecular Biology, Vol.24, No.1-4, pp. 1-7, ISSN 1415-4757 
Vettore, A.L.; da Silva, F.R.; Kemper, E.L.; et al. (2003). Analysis and Functional Annotation of an Expressed Sequence Tag Collection for Tropical Crop Sugarcane. Genome Research, Vol.13, No.12, (November 2003), pp. 2725-2735, ISSN 1088-9051

$\mathrm{Vu}$, J.C.V. \& Allen-Jr., L.H. (2009). Growth at Elevated $\mathrm{CO}_{2}$ Delays the Adverse Effects of Drought Stress on Leaf Photosynthesis of the $\mathrm{C}_{4}$ Sugarcane. Journal of Plant Physiology, Vol.166, No. 2, (January 2009), pp. 107-116, ISSN 0176-1617

Waclawovsky, A.J.; Sato, P.M.; Lembke, C.G.; Moore, P.H. \& Souza, G.M. (2010). Sugarcane for Bioenergy Production: An Assessment of Yield and Regulation of Sucrose Content. Plant Biotechnology Journal, Vol.8, No.3, (April 2010), pp. 263-276, ISSN 1467-7644

Wang, H.H.; Yin, W.B. \& Hu, Z.M. (2009). Advances in Chloroplast Engineering. Journal of Genetics \& Genomics, Vol.36, No.7, (July 2009), pp. 387-398, ISSN 1673-8527

Wang, J.; Roe, B.; Macmil, S.; Yu, Q.; Jan, E.; Murray, J.E.; Tang, G.; Chen, C.; Najar, F.; Wiley, G.; Bower, J.; Van Sluys, M.A.; Rokhsar, D.S.; Hudson, M.E.; Moose, S.P.; Paterson, A.H. \& Ming, R. (2010). Microcollinearity Between Autopolyploid Sugarcane and Diploid Sorghum Genomes. BMC Genomics, Vol.11, (April 2010), pp. 261, ISSN 1471-2164

Wei, X.; Jackson, P.A.; Hermann, S.; Kilian, A.; Heller-Uszynska, K. \& Deomano, E. (2010). Simultaneously Accounting for Population Structure, Genotype by Environment Interaction, and Spatial Variation in Marker-Trait Associations in Sugarcane. Genome, Vol.53, No.11, (November 2010), pp. 973-981, ISSN 0831-2796

Weng, L.X.; Deng, H.H.; Xu, J.L.; Li, Q.; Zhang, Y.Q.; Jiang, Z.D.; Li, Q.W., Chen, .JW. \& Zhang, L.H. (2010). Transgenic Sugarcane Plants Expressing High Levels of Modified Cry1Ac Provide Effective Control Against Stem Borers in Field Trials. Transgenic Research, Vol.20, No.4 (November, 2010), pp. 1-14, ISSN 1573-9368

Whan, A.; Robinson, N.; Lakshmanan, P.; Schmidt, S. \& Aitken, K. (2010). A Quantitative Genetics Approach to Nitrogen Use Efficiency in Sugarcane. Plant Functional Genetics, Vol.37, No.5, (April 2010), pp. 448-454, ISSN 1445-4408

Yamaguchi-Shinozaki, K. \& Shinozaki, K. (2006). Transcriptional Regulatory Networks in Cellular Responses and Tolerance to Dehydration and Cold Stresses. Annu. Rev. Plant Biol., Vol.57, pp. 781-803, ISSN 1040-2519

Yamaguchi-Shinozki, K.; Kasuga, M.; Liu, Q.; Nakashima, K.; Sakuma, Y.; Abe, H.; Shinwari, Z.K.; Seki, M. \& Shinozaki, K. (2002). Biological mechanisms of drought stress response. JIRCAS Working Report, pp. 1-8

Yin, X. \& Struik, P.C. (2010). Modelling the Crop: From System Dynamics to Systems Biology. Journal of Experimental Botany, Vol.61, No.8, (January 2010), pp. 2171-2183, ISSN 0022-0957

Zhangsun, D.; Luo, S.; Chen, R. \& Tang, K. (2007). Improved Agrobacterium Mediated Genetic Transformation of GNA Transgenic Sugarcane. Biologia, Vol.62, No.4, (August 2007), pp. 386-393, ISSN 0006-3088

Zheng, J.; Zhao, J.; Tao, Y.; Wang, J.; Liu, Y.; Fu, J.; Jin, Y.; Gao, P.; Zhang, J.; Bai, Y. \& Wang, G. (2004). Isolation and analysis of water stress induced genes in maize seedlings by subtractive PCR and cDNA macroarray. Plant Mol. Biol., Vol.55, No.6, (August 2004), pp. 807-823, ISSN 0735-9640 


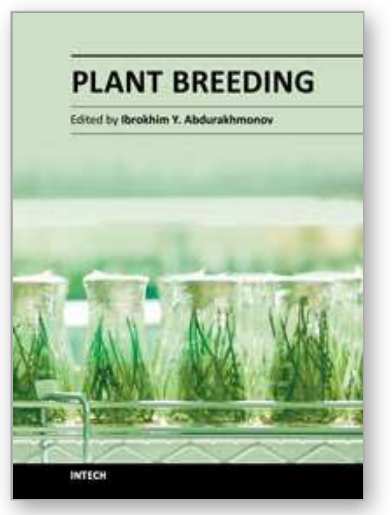

\author{
Plant Breeding \\ Edited by Dr. Ibrokhim Abdurakhmonov
}

ISBN 978-953-307-932-5

Hard cover, 352 pages

Publisher InTech

Published online 11, January, 2012

Published in print edition January, 2012

Modern plant breeding is considered a discipline originating from the science of genetics. It is a complex subject, involving the use of many interdisciplinary modern sciences and technologies that became art, science and business. Revolutionary developments in plant genetics and genomics and coupling plant "omics" achievements with advances on computer science and informatics, as well as laboratory robotics further resulted in unprecedented developments in modern plant breeding, enriching the traditional breeding practices with precise, fast, efficient and cost-effective breeding tools and approaches. The objective of this Plant Breeding book is to present some of the recent advances of 21 st century plant breeding, exemplifying novel views, approaches, research efforts, achievements, challenges and perspectives in breeding of some crop species. The book chapters have presented the latest advances and comprehensive information on selected topics that will enhance the reader's knowledge of contemporary plant breeding.

\title{
How to reference
}

In order to correctly reference this scholarly work, feel free to copy and paste the following:

Katia C. Scortecci, Silvana Creste, Tercilio Calsa Jr., Mauro A. Xavier, Marcos G. A. Landell, Antonio Figueira and Vagner A. Benedito (2012). Challenges, Opportunities and Recent Advances in Sugarcane Breeding, Plant Breeding, Dr. Ibrokhim Abdurakhmonov (Ed.), ISBN: 978-953-307-932-5, InTech, Available from: http://www.intechopen.com/books/plant-breeding/challenges-opportunities-and-recent-advances-insugarcane-breeding

\section{INTECH}

open science | open minds

\section{InTech Europe}

University Campus STeP Ri

Slavka Krautzeka 83/A

51000 Rijeka, Croatia

Phone: +385 (51) 770447

Fax: +385 (51) 686166

www.intechopen.com

\section{InTech China}

Unit 405, Office Block, Hotel Equatorial Shanghai

No.65, Yan An Road (West), Shanghai, 200040, China

中国上海市延安西路65号上海国际贵都大饭店办公楼 405 单元

Phone: +86-21-62489820

Fax: +86-21-62489821 
(C) 2012 The Author(s). Licensee IntechOpen. This is an open access article distributed under the terms of the Creative Commons Attribution 3.0 License, which permits unrestricted use, distribution, and reproduction in any medium, provided the original work is properly cited. 